\title{
The Effect of Tracking Students by Ability into Different Schools:
}

\author{
a Natural Experiment ${ }^{1}$
}

\author{
Nina Guyon ${ }^{a}$, Eric Maurin ${ }^{\mathrm{a}}$ and Sandra McNally ${ }^{\mathrm{b}}$
}

\author{
14 June 2011
}

\begin{abstract}
The tracking of pupils by ability into elite and non-elite schools represents a controversial policy in many countries. There is no consensus on how large the elite track should be and little agreement on the effects of any further increase in its size. This paper presents a natural experiment where the increase in the size of the elite track was followed by a significant improvement in average educational outcomes. This experiment provides a rare opportunity to isolate the overall effect of allowing entry to the elite track for a group that was previously only at the margin of being admitted.
\end{abstract}

JEL Keywords: education; tracking; selection;

JEL Classification: I2.

\footnotetext{
${ }^{1}$ We thank participants at EALE/SOLE conference in London, JMA conference in Angers, EEA conference in Glasgow as well as "Frontier of Economics of Education" conference in Tel Aviv. We are very grateful to the Department of Education, Northern Ireland for providing data and much useful information. In particular, we would like to thank Ivor Graham, John Toogood and Patricia Wyers. We are grateful for helpful comments and information from Tony Gallagher. We thank Patrick Puhani for very helpful discussions and also for information about detracking in Germany. We thank Reyn Van Ewijk and Edwin Leuven for information about detracking in The Netherlands.

${ }^{\text {a }}$ Paris School of Economics (PSE), 48 Boulevard Jourdan Paris 75014. Corresponding author: Eric Maurin, eric.maurin[at]ens.fr.

${ }^{\mathrm{b}}$ Centre for Economic Performance, London School of Economics, Houghton Street, London WC2A 2AE;
} 


\section{Introduction}

The tracking of students by ability into different school types is a widespread, but highly controversial policy, with some countries starting to track as early as age 10 (Germany, Austria) whereas other countries start tracking much later, after the years of compulsory schooling (US, UK, France). The selection of a fraction of high ability students into a subset of elite schools modifies the peer groups and school context for all students. The net impact of such a strategy is extremely difficult to identify, as is the net effect of any education expansion policy relying on increased access to the more elite track. An opposing view is that increases in the size of the elite sector dilutes the value of education received by high ability students, while at the same time negatively affecting the school context of the low and middle ability students who remain in the non-elite sector. It might be argued that such negative contextual effects offset the potentially positive effect of the reform on the group of students who are allowed entry to elite schools and who were only at the margin of being admitted before the expansion policy. In fact, it is even debated whether these marginal students actually benefit from the reform and whether, beyond a certain point, education expansion initiatives generate any positive effect at all. Even in countries where there is no tracking at school-level, this becomes an issue when considering whether we should develop public schools specifically designed for academically talented pupils from deprived neighbourhood, such as various types of "magnet" schools in the US or newly created internats d'excellence in France.

It is very difficult to shed light on these issues. One basic problem is that more selective areas (or countries) differ in many respects to those which are less selective. Hence, a comparison of average outcomes in more or less selective education systems does not provide a credible strategy for evaluating the true effect of educational tracking. Several countries, including Germany and the Netherlands have experienced increases over time in 
the relative size of the most selective track of their lower secondary school system, but these evolutions have been either gradual or caused by reforms that have changed the education system in other ways ${ }^{2}$. Thus, it is difficult to ascertain the specific effects of 'detracking' in these countries. Overall, there is still little convincing evidence about how variation in the relative size of the elite and non-elite tracks affects average educational outcomes (see for example Manning and Pischke, 2006, Figlio and Page, 2002, Betts and Shkolnik, 1999). This is the substantive question that we address in this paper.

We make use of a unique natural experiment where the distribution of students by ability across secondary schools was modified within Northern Ireland at a particular point in time (1989). The secondary school system in Northern Ireland involves the distribution of students across a small set of elite schools and a much larger set of non-elite schools, where elite schools select about a third of students who obtain the best results at a national ability test taken at the end of primary school (at age 11). In 1989, elite schools were required to accept pupils up to a new (larger) admission number determined only by 'physical capacity', where 'physical capacity' was defined on a school-by-school basis by the Northern Ireland Education Department.

This reform led to a significant increase in the overall proportion of pupils in the elite track ('grammar schools') at the beginning of their secondary school education. Furthermore, the impact was very significant in some areas of Northern Ireland, but almost negligible in other areas (plausibly those where elite schools were considered already near 'full capacity' before the reform). This natural experiment allows identification of the effect of an increase in the share of pupils selected into elite schools on average educational attainment, by comparing average outcomes just before and after the reform as well as the distribution of

\footnotetext{
${ }^{2}$ Evidence on the increase in the proportion of pupils attending the most selective track (Gymnasium) over the recent decades in Germany can be found in Bundesministerium für Bildung und Forschung (2008) whereas evidence on the increase in the proportion attending the most academic track ( $v w o$ ) in the Netherlands are provided by Dutch Statistical Office (see time series at http://statline.cbs.nl/Statweb/publication).
} 
average outcomes across local areas just before and after the reform. The attractiveness of this experiment is that the de-tracking reform is the only change that occurred during the period of interest. Most educational expansion reforms have several very different components whose effects cannot be separately identified. To the best of our knowledge, the reform in Northern Ireland is the first where it is possible to isolate the net effect of an increase in the relative size of the elite track. It is important to note that this question is very different from one that investigates the impact of attending the elite track for the marginal student. Our approach identifies the net effect of an increase in the size of the elite track for all students (whether they attended the elite track or not).

We use administrative data covering the entire relevant population to examine the impact of the reform on entry flows to elite schools and the outcomes of affected cohorts. There is a clear discontinuity in the overall inflow to elite schools just after the reform - the number of students entering elite schools increased by about $15 \%$ between the 1978 and 1979 birth cohorts whereas it was reasonably stable for the three preceding and three subsequent cohorts. This discontinuity is reflected in outcome measures. For example, the number of students obtaining 3 or more A-levels at age 18 (i.e. a typical entry qualification for university) increased by about $10 \%$ over the same period whereas it followed the same stable trend as the number attending grammar school in the three preceding and subsequent cohorts. The increase is also reflected in GCSE examinations (General Certificate of Secondary Education), which are the national examinations taken by all students at age 16, just prior to the end of compulsory education. The reform has been accompanied by a clear discontinuous improvement in average educational outcomes which provides the first piece of evidence for a positive effect of increasing the proportion of pupils in the elite track. We show that this is also reflected in university entry rates. 
As expected, our administrative data also reveal significant heterogeneity in the effect of the reform within Northern Ireland across local areas. In some areas, the reform was followed by a very significant shift in the proportion of pupils selected into elite schools. In other areas, the reform produced only very small changes. We find that the reform produced shifts in educational achievement at age 16 or 18 which are much more significant in areas where the initial shift in elite school attendance was stronger.

Thus, the reform makes it possible to provide Instrumental Variable estimates of the effect of school segregation by ability using several different sources of identification. One can make use of the discontinuity across birth cohorts in the average proportion of pupils entering into elite schools. One can also rely on available information on the pre-reform capacity of grammar schools to define the "likely intensity" of the reform in the different areas and develop a difference-in-differences evaluation by comparing strongly and weakly treated areas before and after the reform. Both strategies give estimates of the effect of expanding the elite track which are significant and similar, despite relying on very different identifying assumptions.

The net effect of the reform on average educational outcomes can be interpreted as the combination of three basic factors: the effect of attending an elite school on the group of students who would otherwise have entered a non-elite school; the effect of losing more able peers on the group of students entering non-elite schools after the reform; the effect of having less able peers on the group of students who would have entered the elite school even in the absence of the reform. Separately identifying these effects would amount to identifying the effect of changes in school type (or school context) for different ability groups, which is notoriously difficult. As shown in the last part of the paper, it is nonetheless possible to provide lower bound estimates of these effects by analysing the effect of the reform separately on elite and non-elite school outcomes. Interestingly, we find that the reform had a negative 
effect on average performance in non-elite schools, but not in elite schools, in spite of a decline in the average ability of their students. Hence, elite students do not seem to suffer from attending more heterogeneous schools with additional, relatively less able, peers. Also, students at the margin of being selected to elite schools seem to perform as well as top ability students when they are actually selected into these schools and benefit from a 'high ability' school context. Thus, increasing the share of the elite sector seems to generate positive externalities for mid-ability students, but no negative externalities for top ability students. This is a plausible reason for why this policy has such a strongly positive net effect on average outcomes.

The remainder of the paper is structured as follows. In Section II we briefly discuss the relevant literature. In Section III, we describe the institutional context and the reform. In Section IV, we present our administrative data as well the construction of the panel of local areas in Northern Ireland that is used in the econometric analysis. In Section $\mathrm{V}$ we provide several sets of estimates of the elasticity of the number of students passing national examinations at age 16 or 18 to the proportion selected into elite schools at age 11 . Section VI provides a discussion of our basic results, building on a separate analysis of the effect of the reform on elite and non elite schools. Section VII concludes.

\section{Literature}

There are several recent strands of the UK and international literature on school segregation by ability which are of relevance to our study. Using a panel of about 20 countries, Hanushek and Wößmann (2006) identify the effect of tracked secondary school systems by comparing performance differences between primary and secondary schools across tracked and nontracked systems, where each country's own primary school outcome is included as a control. They find that tracked systems tend to increase educational inequality and to reduce average 
performance to some extent, although this effect is only marginally significant. These findings have been challenged by Waldinger (2006) who finds that results are not stable to using different tracking measures and to restricting the sample to OECD countries.

In a UK context, several studies have compared the outcomes of students living in areas where students are tracked by ability into different schools to those where there is no tracking. Within Great Britain, regional variation in the exposure to a tracked system existed at a time when the system was being transformed (in the 1960s and 1970s) because the abolition of the tracked system in Great Britain only occurred gradually (whereas it did not happen in Northern Ireland). Galindo-Rueda and Vignoles (2004) and Kerkhoff et al. (1996) use variation within Great Britain to estimate the effect of exposure to a tracked system on educational outcomes (regardless of the school type actually attended by an individual). Atkinson et al. (2004) use more recent administrative data to perform a similar analysis in a contemporary setting (the 'selective school' system was retained in a small number of areas in Great Britain). Manning and Pischke (2006) use the same data as that used by Galindo-Rueda and Vignoles (2004) and Kerkhoff et al. (1996), but show that the abolition of the grammar school system was not random across areas. They find that strategies relying on local variation in the degree of selectivity of the school system produce the same results regardless of whether the dependent variable is after the 'treatment' (i.e. age 16 test scores) or before the 'treatment' (age 11 scores). They conclude that caution is required in drawing strong conclusions from studies that rely on the timing chosen by local areas to abolish the tracked system.

A different approach has been used by Clark (2010) to look at the impact of attending grammar schools in one region of England during the 1970s (Yorkshire). He uses a regression discontinuity design, comparing students scoring just below the admission cutoff with those scoring just above. His approach identifies the impact of going to grammar school for the 
marginal student. He finds only small effects on test scores but large effects on academic course-taking and on college enrolment. ${ }^{3}$ This is one piece of evidence to show the positive effects of going to grammar school for the marginal student, although the paper does not address the overall impact of a change in the system (which potentially affects all students).

Our paper is also related to the literature that investigates the effect of within school ability segregation (see, for example, Betts and Shkolnik, 1999, Figlio and Page, 2002, Duflo, Dupas and Kremer, 2008). Using a randomized evaluation applied to primary schools in Kenya, Duflo et al. (2008) find that schools with (maximum) segregation in two equal-sized ability groupings do better than schools with no segregation at all. Also they find that segregation was beneficial to students at all points in the ability distribution. Segregation within primary schools in a developing country is of course not equivalent to segregation across secondary schools in a developed country. For example, the potential negative effect of being assigned to a non-elite group is likely to depend a lot on the age of the students and on the importance placed on educational success in society. Also, it should be emphasised that education expansion reforms (such as that in Northern Ireland) typically involve an increase in the homogeneity of peers for low ability pupils, but a decrease in homogeneity for high ability pupils. It is unlikely to be possible to infer the effects of such policies from experiments where all pupils are affected by the same increase in the extent of homogeneity within the school (in terms of pupil ability).

Finally, our research is also related to the literature ${ }^{4}$ on the impact of the educational expansion reforms that took place in Europe after World War II since de-tracking was often part of these reforms. However the reforms had typically several very different components,

\footnotetext{
${ }^{3}$ These findings are consistent with papers showing that early tracking leads to substantially different schooling experience across students who differ only with respect to their exact date of birth within the year (Mülhenweg, Puhani, 2010). Also they are consistent with literature looking at the impact of attending elite schools for marginal students in other contexts (Cullen, Jacob and Lewit, 2006; Altonji, Elder and Taber, 2005).

${ }^{4}$ See e.g. Meghir and Palme (2005) for the Sweden, Pekkarinen, Uusitalo and Pekkala (2009), for the Finland, Aavik, Salvanes and Vaage (2010) for Norway, Maurin and McNally (2008) and Gurgand and Maurin (2006) for France.
} 
including increases in school leaving age. Hence, outcomes cannot be attributed to the specific effect of de-tracking. A distinguishing feature of our study is that the natural experiment under consideration has not modified the nature of the school system but only modified the relative size of the elite sector. To identify the effect of widening access to the academic track on average outcomes, we rely on comparisons between children who go to school in the same educational system, where marginal reforms are made to that system rather than involving conversion to a different type of system. To the best of our knowledge, this experiment is the first to isolate the overall contextual effect of allowing entry to the elite track for a group that was previously only at the margin of being admitted.

\section{Institutions and reform}

In a number of key respects, the education system is the same in Northern Ireland as that in England and Wales. Pupils spent six years in primary school, from age 5 to age 11 , and then five additional years in secondary school, until age 16, the minimum school-leaving age. At the end of compulsory education (age 16), all students take GCSE examinations. It is usual for students to take 8 to 10 subjects, including English and Math. There is an externally set and marked exam for each subject (pass grades are $A^{*}, A, B, C \ldots . G$ and then a fail). Anything from grade $A^{*}$ to grade $C$ is regarded as 'good' and the standard outcome measure for a student is whether he/she achieves 5 or more grades at $A^{*} C^{5}$. The National Qualifications Framework (NQF) used by UK employers consider grades $D-G$ as a level 1 qualification; grades $A^{*} C$ as level 2 ( $A$-level being at level 3$)$. The proportion of students achieving 5 or more grades at $A^{*} C$ is also the key national indicator to measure performance at the end of compulsory schooling (and applies to England, Wales and Northern Ireland). In the UK, many studies find that qualifications which mark the end of compulsory education have a very large

\footnotetext{
${ }^{5}$ Students might not be allowed to continue in a subject to A-level if they had not managed to get a $C$ in it for GCSE.
} 
impact on labour market outcomes. In terms of data and methodology, one of the most convincing studies is by Blundell et al. (2005) who found a wage return of $18 \%$ for those entering the labour market with these qualifications versus stopping at age 16 without qualifications (see also McIntosh, 2006).

If the student decides to pursue academic education beyond GCSE, this involves studying for A-level exams which normally requires an extra two years of study. These examinations are externally set and graded and are the usual entry route to university. Compared to leaving school without qualifications, Blundell et al. (2005) finds an average wage return of $24 \%$ for those completing A-levels only, which rises to $48 \%$ for those completing higher education.

The education system in England, Wales and Northern Ireland is also similar in that they operate under a similar legislative framework and have a similar National Curriculum ${ }^{6}$. However, in Northern Ireland, there is still a selective system of secondary education whereas England and Wales largely converted to the comprehensive model in the 1960s and 1970s. ${ }^{7}$ This change almost happened in Northern Ireland as well but plans were halted following the election of the Conservative government in 1979.

\section{A Tracking of students by ability in Northern Ireland}

Unlike the comprehensive system (where schools are not allowed to select on the basis of academic ability), the selective system in Northern Ireland involves a test at age 11 which determines the type of secondary school a child will attend: grammar schools (for the more academically able) or other secondary schools. Between 1981 and 1994 (i.e. cohorts born in

\footnotetext{
${ }^{6}$ Important Acts are the 1944 Education Act for England and Wales and the 1947 Act for Northern Ireland; the 1988 Education Reform Act in England and Wales and the Education Reform (Northern Ireland) Order 1989.

${ }^{7}$ Other important differences are religious segregation in the education system of Northern Ireland: most Catholics attend schools under Catholic management ('maintained') whereas most Protestants attend other state schools. Also, there are many more single sex schools in Northern Ireland - 25\% compared to $16 \%$ in England. Of single sex schools, about $45 \%$ are grammar schools (i.e. those that select the more academically able).
} 
1970 and 1983), the transfer test was based on two tests of the verbal reasoning type with some questions designed to test specific aspects of English and mathematics (Sutherland, 1993). ${ }^{8}$ On the basis of performance in these tests, pupils were awarded one of three grades (Grade A awarded to the top 20\%; Grade B awarded to the next 10\%). Pupils were admitted to grammar schools (or not) on the basis of performance on these tests. ${ }^{9}$ Within this framework, the key difference between grammar and other secondary schools is in their pupil composition in terms of ability - along with the consequences this has for the teaching environment and the ethos of the school. Gallagher and Smith (2000) suggest that the 'grammar school effect' is explained by a combination of the clear academic mission of schools, high expectations for academic success on the part of teachers and the learning environment created by a pupil peer group which is selected on academic grounds. All of these factors combine to make the education experience very different in grammar schools than in other secondary schools, even though they operate under the same National Curriculum and implement the same public examinations. In contrast, there is no suggestion in the literature that this effect could be explained by differences in funding between sectors. Funding to schools in both sectors is largely driven by pupil numbers. ${ }^{10}$

Unfortunately we do not have information on how exactly schools responded to changes in funding after the reform. However, note that the new maximum admissions number was based on 'capacity constraints' at each individual school, thus deliberately avoiding any dramatic change (e.g. change involving new buildings for instance). All schools are expected to apply the same National Curriculum which prescribes, in detail, the range of

\footnotetext{
${ }^{8}$ In 1993/94, the transfer tests were changed from a verbal reasoning to a curriculum orientated format. This affects cohorts born from 1983 onwards.

${ }^{9}$ Prior to the 1989 reform, the intake to each grammar school was determined by a formula which would keep the overall intake of grammar schools to a fixed proportion overall (Dept of Education, 1986).

${ }^{10}$ Any change to enrolment in schools on account of the 1989 reform would have led to a corresponding change in funding in accord with the number of pupils. Unfortunately we do not have information on how exactly schools responded to changes to admissions. However, 'capacity constraints' were taken into account when devising the new maximum admissions number for schools. Hence individual schools were protected against any dramatic changes.
} 
subjects which must be taught at all levels of compulsory education; the relative time allocation to different areas of the curriculum; and the actual course content for the various subjects (see Morgan, 1993). While grammar schools and other secondary schools operate under this same framework, in practice, there is some evidence of heterogeneity in the curricula actually implemented by schools, with pupils in a sample of grammar schools spending more time at academic subjects (particularly languages) than their counterparts in a sample of other secondary schools (Harland et al., 2002).

The same public examinations are taken in both school types (GCSE at age 16, Alevels at age 18). In all grammar schools and in many other secondary schools, it is possible to stay on for 2 extra years. ${ }^{11}$ Although school type is highly correlated with the probability of obtaining A-levels (reflecting the selection process as well as any genuine 'school' effect), there is no automatic relationship between entering grammar school and achieving A-levels or entering other secondary school and failing to achieve them. Before the reform about $78 \%$ of pupils attending grammar school achieved at least one A-level whereas this was true of $6.6 \%$ of those attending non-grammar schools. With regard to GCSEs, the percentage of students achieving 5 or more GCSEs at $\mathrm{A}^{*}-\mathrm{C}$ was 91 per cent and 22 per cent in grammar schools and non-grammar schools respectively.

\section{B The 1989 Reform}

As explained above, it was a political accident that Northern Ireland did not abolish 'selective schooling' at the same time as the rest of the UK in the 1960s and 1970s. As a consequence, the system of very early tracking (i.e. at age 11) has been maintained in Northern Ireland up to the present day, whereas in other respects the education system has remained similar to that in other parts of the UK. However, an important reform to grammar school admission was

\footnotetext{
${ }^{11}$ It is also possible to study for A-levels in colleges of further education. However, the majority of students in Northern Ireland who obtain A-levels do so when at school.
} 
implemented in Northern Ireland in the late 1980s. This involved a rise in the level of quotas applied to grammar school intakes. Following the Education Reform (Northern Ireland) Order 1989 (implemented from 1990 and affecting cohorts born from 1979), grammar schools were required to accept pupils, on parental request, up to a new (larger) admission number determined by the Department of Education and based only on the physical capacity of the school. This 'open enrolment' reform was in the spirit of making the education system more amenable to parental choice. Between 1985 and 1989 (before the reform), about 8,100 pupils (31\% of the cohort) entered grammar schools each year, whereas this increased to about 9,400 pupils (35\% of a cohort) just after the reform, between 1989 and 1992 (i.e., between cohorts born from 1979 to 1982, see Figures 1 and 2).

The reform generated a $15 \%$ increase in the number of students attending grammar school, for a time period in which cohort size was relatively stable. This corresponds to an $11 \%$ increase in the probability of attending grammar school between the 1978 and 1979 cohorts, whereas this probability was fairly stable immediately before the policy (1976-78) and immediately afterwards (1979-81).

The Northern Ireland Council for Educational Research (NICER) carried out a series of studies before and after the reform which provides information on academic level of the "marginal" students, i.e. students observed in grammar schools after the reform but who would not have been admitted before (see Wilson, 1986, Gallagher and Smith, 2000). Specifically, according to the NICER, the probability of grammar school enrolment for pupils ranked among the top 30\% at the transfer test (grade A or B) is almost as high during the prepolicy period as during the post-policy period (88\% in $1981-1985,92 \%$ in $1993-1997)$. By contrast, the probability of grammar school enrolment for pupils ranked among the bottom $70 \%$ at the transfer test (grade C or below) was almost negligible pre-policy (4\% in 19811985), but become much more significant post-policy (19\% in 1993-1997). Overall, pupils 
ranked among the bottom $70 \%$ at the transfer test represented about $9.6 \%$ of the grammar school population pre-policy, but almost $32.5 \%$ post-policy. The main effect of the reform is a significant increase in the proportion of medium-ability students within grammar schools.

The raising of quotas on grammar school intakes was controversial because of the fear that grammar schools would 'cream-skim' the highest ability students from other secondary schools and that all would suffer as a result. A concern voiced by the Northern Ireland Economic Council (1995) was that the reform could undermine the selective system: 'The educational impact of allowing the grammar school sector to expand needs to be questioned. The fundamental point of such a system is that educating the more academically able is seen as being of benefit to both the more and least able. By definition, it would seem that allowing students who previously would have entered a secondary environment to attend a grammar school must inevitably dilute the perceived value of selective education...' Our evidence allows us to consider what reducing selectivity did to educational credentials in the overall population.

\section{Data and variables}

We use two administrative data sets that were obtained from the Department of Education in Northern Ireland. The first one provides annual school-level information on the number of pupils entering each grade. The second data set provides school-level data on all school leavers by grade and year. ${ }^{12}$ Also, this data set contains information on national examination outcomes and key indicators of qualifications attained. Both data sets contain information on the name, religious affiliation (Catholic or Protestant), location and type of school (grammar or non-grammar). Note that these datasets cover the entire population of secondary schools, except independent schools. In Northern Ireland only a small percentage of pupils attend

\footnotetext{
${ }^{12}$ This is called the School Leavers Survey and is actually a census of all school leavers. It contains details of all their qualifications, although we do not have information on the score obtained in the admission test for grammar school.
} 
independent schools (less than 1 per cent) and this has not changed over the time period of interest to us.

We use these administrative datasets to build a panel of 23 local areas with information on the proportion of pupils attending grammar schools and average examination outcomes for each local area and each cohort born between 1974 and $1982 .^{13}$ We created these local areas on a geographic and religious basis: first we divide the set of all schools in Northern Ireland by religious denomination ${ }^{14}$ (for the most part, Catholics attend either Catholic grammar or non-grammar schools; Protestants attend Protestant grammar or nongrammar schools). Second, we match each non-grammar school to the grammar schools of its local administrative district (LAD). Education at a local level in Northern Ireland is administered by five "Education and Library Boards" (ELB) covering different geographical zones (Belfast, North Eastern, South Eastern, Southern, Western) and these ELB are divided in 26 LAD. Whenever a LAD does not contain any grammar school of a given religious denomination we match the corresponding non-grammar schools of this LAD to an adjacent $\mathrm{LAD}^{15}$. Finally, we merge some additional adjacent LADs in order to eliminate small areas with erratic size. Overall, we obtain a total of 23 areas (10 Catholic and 13 Protestant) such that the proportion of pupils found in each area is very stable across cohorts. There is, for example, no significant difference in the average number of pupils in each area before and after the reform, which is consistent with the assumption that the reform has mostly affected the allocation of students across schools within areas and not across areas ${ }^{16}$.

\footnotetext{
${ }^{13}$ Since grade repetition is not a feature of the school system in the UK, it is possible to derive birth cohort using available information on grade and date (i.e., cohort $=$ date - grade). The birthday cutoff for school entry being July the $1^{\text {st }}$, each cohort corresponds to children born between the $1^{\text {st }}$ of July and the $30^{\text {th }}$ of June of two consecutive years (for example cohort 1974 refers to children born between July $1^{\text {st }} 1973$ and June $30^{\text {th }} 1974$ ).

${ }^{14}$ There are 113 Catholic schools ( 31 grammar and 82 non grammar) and 143 Protestant schools (40 grammar and 103 non grammar) in Northern Ireland.

${ }^{15}$ We observe $4 \mathrm{LAD}$ without any Protestant grammar school, 11 LAD without any Catholic grammar school.

${ }^{16} \mathrm{~A}$ chi-squared test shows that there is no significant difference in the distribution of pupils across the 23 areas just before the reform (cohort 1978) and just after the reform (cohort 1979).
} 
With respect to religion and size, our procedure yields one large Protestant area (with 11 grammar schools) and one large Catholic area (with 7 grammar schools) in the Belfast region, plus 12 smaller Protestant and 9 smaller Catholic areas outside Belfast (with on average 2.6 grammar schools in each of these smaller areas). Each large Belfast area represents about $12 \%$ of the population of pupils whereas each smaller area represent on average $3.6 \%$ of the population (see Appendix table A1).

Within this framework, our basic research question is whether the reform to grammar school admission had any influence on the number of students achieving 5 or more GCSEs at grades $\mathrm{A}^{*}-\mathrm{C}$ at age 16 or achieving A-levels at age 18. As discussed above, GCSE is the compulsory examination taken by all students at age 16 and A-levels are the examinations taken by a subset of students interested in pursuing academic education beyond the compulsory phase. We have information on key indicators of achievement in both of these examinations (used in this paper), although not the full range of scores. Data are available for cohorts born between 1974 and 1982, for which there were no major reforms to A-levels, or to the age 16 examinations or to the transfer tests determining entry to grammar school (see descriptive statistics in Appendix Table A2). As it happens, reforms to the A-level system have taken place in 1987/88 (affecting cohorts from 1972 onwards) and in 2000 (affecting cohorts from 1984 onwards) whereas reforms to the examination taken at age 16 by all pupils (GCSE - formerly O-levels) took place in 1988 (affecting cohorts from 1972 onwards), but no reforms took place for cohorts born between 1972 and $1988^{17}$. To illustrate this, Figure 3 shows the change in our measures of educational success in England ${ }^{18}$ for the cohorts born before and after the reform under consideration (i.e., before and after 1978). We do not find

\footnotetext{
${ }^{17}$ As discussed above, reform to the transfer test affected cohort born form 1983 onward. The Universities and Colleges Admission Service (UCAS) provide a detailed account of these reforms and what the examinations consist of.

${ }^{18}$ Pre-reform information is not available for exactly the same cohorts in England and Northern Ireland. With regard to GCSEs in England, we have used school-level information from the School Performance Tables that is available from 1992 onwards i.e., cohorts from 1976 onwards. With regard to A levels, we have used pupil level information, which gives comprehensive coverage of the results of all students taking A-levels in England and which is available from 1993 onwards (enabling us to consider outcomes from the 1975 cohort).
} 
any significant shift at the time of the reform. We observe the same smooth increase in the proportion of successful students across cohorts born before and after the reform (about a 1 percentage point increase per year). Given that the examination system at age 16 and 18 is exactly the same in England and Northern Ireland, this figure provides further support to the assumption that examination procedures and the overall ability to pass examinations did not undergo any discontinuous change in Northern Ireland at the time of the reform. In the next section, we build on this assumption to provide several estimates of the effect of early detracking on subsequent average educational outcomes.

\section{Educational Effects of the Reform}

In this Section, we estimate the educational effects of the reform using different identifying assumptions. We use a simple model where the number of students who pass their exams at the end of secondary education (i.e. at age 16 or 18) in area $i$ and cohort $c$ depends on (a) the total number of students who enter secondary education in area $i$ and cohort $c$ and (b) the distribution of students across elite and non-elite schools in area $i$ and cohort $c$. Specifically, we assume the following model of education production:

(1) $Y_{i, c}=\alpha+\beta G_{i, c}+\gamma S_{i, c}+\theta_{0}(c)+u_{i}+\varepsilon_{i, c}$

where $Y_{i, c}$ represents the number of students who pass their exams at age 16 (or 18) in area $i$ and cohort $c, S_{i, c}$ the total number of pupils who enter into secondary education in area $i$ and cohort $c$ and $G_{i, c}$ the proportion of pupils selected into elite schools at age 11 in area $i$ and cohort c. Variables $Y_{i, c}, G_{i, c}$ and $S_{i, c}$ are specified in $\log$ format so that parameter $\beta$ can be directly interpreted as the educational effect of a $1 \%$ increase in admission numbers in elite schools, holding cohort size constant. Variable $\theta_{0}(c)$ captures any continuous cohort trends that may affect the proportion of successful students either before or after the reform: we use 
a spline function with a knot at the reform date ${ }^{19}$. The variable $u_{i}$ represents fixed effects which capture permanent differences in outcomes across areas. Finally $\varepsilon_{i, c}$ represents cohortspecific shocks to pupils' ability to pass examinations at age 16 (or 18) in area $i$. Within this framework, the parameter of interest is $\beta$ which captures the effect of school segregation by ability on educational outcomes. The basic identification issue comes from the fact that cohort-specific shocks to student ability $\varepsilon_{i, c}$ may be correlated with the cohort-specific shocks to the proportion of students selected into elite schools ${ }^{20}$. In such a case, the OLS regression of $Y_{i, c}$ on $G_{i, c}$ provides a biased estimate of $\beta$, even after de-trending and purging out fixed effects. To address this issue, we first make use of the discontinuous shift affecting the average level of elite school attendance as a consequence of the reform.

\section{A Change in Average Elite School Attendance After the Reform}

Assuming that there is no discontinuity in average ability to pass exams at the time of the reform in Northern Ireland, parameter $\beta$ is identified as the ratio of the shift in the proportion of successful students and the shift in the proportion of pupils in elite schools observed just after the reform. It can be estimated in Model (1) using a 'reform on' dummy $1\left(c>c_{0}\right)$ as an instrumental variable (where $c_{0}$ is the last unaffected cohort).

Before moving on to the estimation results, it is of interest to consider Figures 4 to 6 , which use the area-level data to show variation across cohorts in the average proportion of grammar school students and average number of successful students at age 16 (or age 18). Interestingly, they reveal a significant discontinuity in both variables at the reform date ${ }^{21}$, which is consistent with the hypothesis that variation in the proportion of students selected

\footnotetext{
${ }^{19} \theta_{0}(c)$ is written $\theta_{01} c+\theta_{02}\left(c-c_{0}\right) 1\left(c>c_{0}\right)$ where parameter $\theta_{01}$ captures pre-reform cohort trend whereas parameter $\theta_{02}$ represents the change in cohort trend after the last unaffected cohort $c_{0}$.

${ }^{20}$ Suppose for example that the proportion of students selected into grammar school in area $i$ tends to be larger for cohorts that happen to have a larger proportion of very good students in area $i$ (in an absolute sense). In such a case, $Y_{i, c}$ and $G_{i, c}$ will be correlated even if there is no causal effect of $G_{i, c}$ on $Y_{i, c}$.

${ }^{21}$ Note that these shifts cannot be interpreted as reflecting changes happening at one point in time (changes in evaluation practices for instance) since they correspond to the same cohort shift observed at different ages.
} 
into elite schools at age 11 affected the number of successful students at age 16. For example, the reform generated an increase of about $14 \%$ in our measure of success at age 18 , whereas it was only weakly increasing in the pre-reform period and it is stable in the period immediately post policy.

Table 1 provides the result of the corresponding regression analysis. Column 1 shows the results of the first-stage regression,

(2) $\quad G_{i, c}=\delta+\pi 1\left(c>c_{0}\right)+\gamma_{1} S_{i, c}+\theta_{1}(c)+v_{i}+v_{i, c}$.

where $1\left(c>c_{0}\right)$ is a dummy indicating that the reform is on whereas $\theta_{l}(c)$ is a spline function with a knot at $c_{0}$ (i.e., $\left.\theta_{1}(c)=\theta_{11} c+\theta_{12}\left(c-c_{0}\right) 1\left(c>c_{0}\right)\right)$. It confirms a significant discontinuous increase in $G_{i, c}$ at the date of the reform. The estimate of $\pi$ is positive and significant at standard levels. Columns 2 and 3 show the results of reduced form regressions. These confirm that there was a shift in the number of successful students (either at GCSE or A-level) at the date of the reform which is parallel to that observed for the proportion of students selected into elite schools for the relevant cohort. Columns 4 and 5 show results for the corresponding second stage regressions, which suggest that a $10 \%$ increase in the proportion of students selected into elite schools generates a $4.1 \%$ increase in the number of successful students at age 16 and a $7.5 \%$ increase at age 18 . These estimates are actually quite close to the basic OLS estimates $^{22}$ (see Columns 6 and 7). With respect to the effect of cohort size, it remains close to 1 and statistically not different from 1 , which suggests that there are no significant economies (nor diseconomies) of scale in the educational production function. Changes in average school size in an area have, as such, no effects no average outcomes.

\footnotetext{
${ }^{22}$ One possible reason for the similarity of OLS and IV estimates is that they use the same basic source of identification. As it happens, putting aside the year of the reform, the probability of selection into grammar schools is the ratio between a quasi constant number of places and a more fluctuating cohort size (see Figure 2). Thus, the unobserved shocks to the selection probability in fact coincide with shocks to cohort size. Given that these shocks are absorbed in our regressions by the control variable $S_{i}$, the only remaining source of identification in an OLS regression of $Y_{i c}$ on $G_{i c}$ is the shift in $G_{i c}$ at the time of the reform, i.e., exactly the same source of identification as the IV.
} 
In Appendix B, we report the results of several additional robustness analyses. To start with, appendix Table B1 shows the results of using alternative specifications for both the dependent and independent variables and we obtain very similar results. For example, the results remain qualitatively unchanged when we do not use (log) cohort size as a control variable and regress the $(\log )$ proportion of successful students on the (log) proportion of students enrolled in grammar schools (see specification 2). We prefer the specification where no constraint is imposed on the effect of cohort size since it is not obvious ex ante whether and how cohort size affects the quality of education and probability of success in an area ${ }^{23}$. We have also checked that the different specifications provide qualitatively similar results when we regress the proportion of successful students on the proportion of students selected to an elite school (rather than the log proportion, see specifications 3 and 4 in Table B1). Nonetheless, the specification in logs seems better adapted to the right-skewed distribution of cohort size and provides a slightly more precise IV estimate.

Regardless of specification, the regression analysis in Table 1 relies on the assumption that unobserved determinants of educational outcomes in Northern-Ireland did not change discontinuously after the reform. Appendix Table B2 provides the results of an alternative strategy, where we do no longer exclude discontinuous shifts, but where we assume that such shifts (if any) have affected Northern Ireland and England in the same way. Specifically, we consider England as an additional area (where $G_{i, c}$ is set to zero) and the effect of grammar school enrolment is identified using the interaction between a Northern Ireland dummy and a "reform on" dummy as an instrumental variable, holding constant a full set of cohort fixed effects and area fixed effects. This amounts to using England as a control group in a standard

\footnotetext{
${ }^{23}$ Generally speaking, grammar school enrolment in an area depends on "demand" factors (typically cohort size) as well as on "supply" factors (schools' capacity), but the reform under consideration affected grammar school enrolment only through its effect on "supply" factors. In such a case, the effect of the reform on enrolment is better captured by a specification where we hold "demand" factors (such as cohort size) constant. This is reflected by the more precise first stage estimates obtained by this specification in our simple difference analysis.
} 
difference-in-differences setting ${ }^{24}$. This approach yields estimated impacts that are very similar to those in Table 1 for age 18 outcomes and larger estimates for age 16 outcomes (although the difference between the two estimates is not significant at standard levels).

Overall, this initial analysis suggests that when the share of the elite track is exogenously expanded in an area, the average outcomes improved. Further investigations (not reported) suggest that the effects are perceptible for the group of areas with a relatively high pre-reform share of elite track as well as for the group with a relatively low pre-reform share. More generally, our data do not make possible to identify an "optimal" share above which further increase in the elite track become ineffective. It does not mean that such an "optimal" size does not exist, but it cannot be identified with the natural experiment used in this paper.

Finally, it should be emphasized that Table 1 provides cluster robust estimates of standard errors, using the generalized White procedure (White, 1984), where clusters correspond to cohorts. As pointed out by Moulton (1990), statistical inference on aggregated regressors (such as our "reform on" dummy) requires clustering at that level ${ }^{25}$. As additional check, we have re-estimated model (1) after aggregating outcomes at the cohort level. This approach may lack power, but it is the simplest way to account for the finite sample biases that may affect cluster robust estimates of standard errors when the number of clusters is small (Donald and Lang, 2007, Cameron and Miller, 2010). Comfortingly, this approach provides us with estimates of the effect of the reform that are very similar to those in table 1 and which remain significant at standard levels, even after adjusting tests for the small number of degrees of freedom in these aggregated regressions (see panel A of Table B4).

\footnotetext{
${ }^{24}$ Alternatively, we could re-estimate model (1) using the difference in average outcomes between areas in Northern Ireland and England as the dependant variable (i.e., using $Y_{i, c}-Y_{0, c}$ rather than $Y_{i, c}$ as the dependant variable, where $Y_{0, c}$ represents English outcomes) and using a full set of cohort fixed effects (rather than a spline function) in the set of control variables. We have checked that this estimation strategy provides similar estimates.

${ }^{25}$ In our specific case, however, estimated standard errors are similar regardless of whether we use robust cluster estimates or not.
} 


\section{B $\quad$ Change in the Distribution of Elite School Attendance Across Areas}

The analysis in Table 1 provides an estimate of the effect of the reform under the assumption that other national-level determinants of educational outcomes did not undergo a discontinuous shift in Northern Ireland at the time of the reform. In this sub-section, we provide an evaluation relying on a completely different assumption, using a feature of the reform that we have not yet exploited. Specifically, we make use of the fact that the reform did not have the same impact on the proportion of pupils in elite schools in different areas of Northern Ireland. As discussed above, the effect of the reform in a given area was determined only by local capacity constraints. Hence, the effect of the reform on grammar school entry was determined in each local area by parameters that had plausibly nothing to do with the variation in pupils' ability to pass exams across cohorts. In such a case, the educational effect of increasing the proportion of pupils entering elite schools in an area can be identified by evaluating whether the most affected areas are also those which experienced the largest improvement in educational outcomes after the reform. Specifically, under the maintained assumption that the area-specific changes in $v_{i, c}$ between post-reform and pre-reform cohorts are uncorrelated with the area-specific changes in $\varepsilon_{i, c}$ across the same periods, we can evaluate parameter $\beta$ by estimating Model (1) after taking long-differences between post-reform and pre-reform period,

$$
\mathrm{Y}_{i, \text { after }}-\mathrm{Y}_{i, \text { before }}=\delta+\beta\left(\mathrm{G}_{i, \text { after }}-\mathrm{G}_{i, \text { before }}\right)+\gamma\left(\mathrm{S}_{i, \text { after }}-\mathrm{S}_{i, \text { before }}\right)+\left(\varepsilon_{i, \text { after }}-\varepsilon_{i, \text { before }}\right)
$$

where, for each variable $x_{i c}, x_{i, \text { after }}$ represents the mean of $x_{i c}$ in area $i$ across post-reform cohorts and $x_{i, \text { before }}$ represents the mean of $x_{i c}$ in area $i$ across pre-reform cohorts. Note that this second strategy provides an estimate of $\beta$ even in the case where there is a nation-level discontinuity in pupils' average ability at the time of the reform, i.e. even when our first 
identification strategy ${ }^{26}$ provides a biased estimate of $\beta$. Also this second strategy does not necessarily coincide with the fixed effect OLS estimate of model (1) since it relies on the sole change observed at the time of the reform whereas the fixed-effect OLS evaluation uses all observed fluctuations for identification. Table 2 shows the result of estimating Model (3). Panel A uses the full set of available cohorts (i.e. 1974-1982) and provides estimates using the difference in mean educational outcomes between the four post-reform cohorts and the five pre-reform ones as the dependant variable. By contrast, Panel B focuses on the sole two prereform and two post-reform cohorts (i.e., 1977-1980) and provides estimates using the difference in mean educational outcomes between the two post-reform and the two pre-reform cohorts as the dependant variable. Comfortingly, the regression results are very similar across the two specifications. However, one potential issue with these specifications is that the change in grammar school enrolment in an area may be related to local transitory shocks to pre-reform cohort characteristics (Ashenfelter's dip). For example, it may be larger in areas where pre-reform cohorts show relatively low educational ability compared to average cohorts in the same area. In such a case, the correlation between the change in grammar school enrolment and the change in educational outcomes in an area may reflect the fact that these two variables depend on the same transitory variation in cohorts' unobserved characteristics and may overestimate the true effect of the reform on outcomes. To test for this effect, panel C replicates the same analysis after dropping the two pre-reform cohorts (1977 and 1978). Again, we find similar results. Overall, this "long difference" analysis suggests that a $10 \%$ increase in the proportion of grammar school entrants generates an increase of about $4 \%$ in the number of students obtaining 5 or more GCSEs at grades $\mathrm{A}^{*}-\mathrm{C}$ and an increase of about $7 \%$ in the number of students with 3 A-levels or more at age 18. Most interestingly, this estimated elasticity is very close to the estimates obtained in the previous sub-section even

\footnotetext{
${ }^{26}$ As it happens, the two strategies rely on two different sources of identification: the change in the average level of elite school attendance over time (first strategy) vs. the change in the distribution of elite school attendance across areas (second strategy).
} 
though the source of identification is completely different. The first strategy used the nationlevel discontinuity in the relationship between entry to elite schools and cohort of birth whereas the second strategy uses the differential impact across areas as a source of identification. Figures 7 and 8 show graphically that there is a very clear correlation between area-level variation in the proportion of successful students at age 16 (5 or more GCSEs at grades $\left.\mathrm{A}^{*}-\mathrm{C}\right)$ or at age 18 (3 A-levels or more) and area-level variation in the proportion of students selected into grammar schools.

In substance, the identifying assumption used in this sub-section is that the change in students' average ability after the reform is not particularly strong (nor weak) in areas where the reform implied a strong increase in grammar school capacity. One potential issue is that some families may have moved into these areas after the reform in order to benefit from the increase in enrolment to elite schools. Consequently, the number and average ability of pupils may have changed at the same time as the enrolment capacity of elite schools in these areas, which could create a bias in the OLS estimates of Model (3). In such a case, however, we should observe a positive correlation between the change in the size of the elite sector in an area and the change in the total number of students in this area after the reform. As shown by the last column of Table 2, this is not the case: there is no positive association between the change in the size of elite schools and the change in the total number of students after the reform. When we focus on the two pre-reform and two post-reform cohorts, this also confirms that the reform has not been associated with any significant reallocation of students from weakly affected to strongly affected areas. Appendix table B3 provides additional evidence showing that the reform did not coincide with any significant reallocation of pupils from low socioeconomic backgrounds across strongly and weakly affected areas. In our data, eligibility to receive free schools meals is the available measure of socio-economic background. This is an entitlement for families who are on various types of income support. It represents a good 
proxy for the proportion of families in the lowest quartile of the income distribution ${ }^{27}$. When we replicate regression models (2) or (3) using this proxy as dependent variable, we do not find any evidence that the reform has been associated with a significant change in the distribution of pupils eligible to receive free school meals across cohorts or across areas (Table B3, columns 1 and 2).

\section{Differences- in- Differences analysis}

The previous "long difference" approach is potentially problematic since actual attendance rates may have increased to a greater extent in places where the academic potential of students increased by more just after the reform. To further explore the robustness of our results, it would be interesting to have administrative data on schools' capacity before the reform and to use this information to construct a measure of the "likely intensity" of the reform across areas. It would then be possible to test whether stronger "likely intensity" of the reform in an area is associated with stronger improvement in educational outcomes after the reform. Unfortunately, we do not have such direct information on schools' capacity. It is nonetheless possible to construct a proxy (denoted $T_{i}$ ) by considering the fluctuations in grammar school enrolment across cohorts before the reform. In areas where grammar schools are near full capacity, grammar school enrolment should not fluctuate a lot and the impact of the reform on grammar school enrolment should not be very large.

To conduct this difference-in-differences analysis, we have taken our measure of "likely intensity" of the treatment $T_{i}$ to be the coefficient of variation of the distribution of the number of pupils enrolled in grammar schools across pre-reform cohorts in area $i$ and we have assumed an extended version of model (1),

$$
Y_{i c}=\alpha+\beta G_{i c}+\gamma S_{i c}+\tau_{c}+u_{i}+\varepsilon_{i c}
$$

\footnotetext{
${ }^{27}$ Information on free school meals is missing for cohorts 1974 and 1975, which explains why the analysis in Appendix table B3 is conducted cohorts 1976-1982 only.
} 
where $\tau_{c}$ represents cohort fixed effects, $u_{i}$ represents area fixed effects and where the difference in average ability $\varepsilon_{i c}$ across high- $T_{i}$ and low- $T_{i}$ areas is assumed to be the same before and after the reform. Under this maintained assumption, parameter $\beta$ is identified even when there is a change in average ability at the reform date $c_{0}$, i.e. even when OLS estimation of model (3) is biased. Specifically, we can use the interaction between our measure of treatment intensity $T_{i}$ and a reform dummy as an instrumental variable. $\beta$ is identified as the ratio between the shift in the difference in student achievement at the reform date across low and high treatment intensity, areas and the corresponding shift in the difference in grammar school attendance at the same cut-off date.

To start with, column (1) of Table 3 shows the corresponding first-stage regression,

$$
\text { (5) } \quad G_{i c}=\delta+\pi l\left(c>c_{0}\right) \mathrm{x} T_{i}+\gamma S_{i c}+\tau_{c}+u_{i}+\varepsilon_{i c}
$$

Comfortingly, the estimate of $\pi$ is significantly positive which confirms that the reform was followed by a larger increase in grammar school enrolment in areas where fluctuations in grammar school size before the reform were the largest. This result is consistent with our working assumption that pre-reform fluctuations in grammar school enrolment provide a good proxy for the "likely intensity" of treatment. Columns (2) and (3) show the reduced form regressions which reveal that the larger increase in grammar school enrolment observed in high-intensity, areas is accompanied by a stronger increase in the number of successful students in these areas. This finding is obviously consistent with the result obtained in the previous sections that educational outcomes in an area are causally affected by the proportion of students admitted to grammar schools in this area. Columns (4) and (5) show the corresponding IV estimates. The estimated effects on the number of successful students at age 16 or at age 18 are significant at standard levels and very similar to estimates obtained in the previous sections. Finally, the last column of the table shows that there is no significant change in the relative size of high intensity areas after the reform. The reform has not 
generated any significant reallocation of students and families across low intensity and high intensity areas. Using the proportion of students eligible to receive free school meals as the dependent variable (the last column of Appendix table B3) further confirms that the reform is not associated with any statistically significant change in the relative social background of pupils in high intensity areas. These results are consistent with the identifying assumption that changes in students' characteristics after the reform are unrelated to the likely intensity of the reform (as captured by $T_{i}$ ).

One possible issue with difference-in-differences (DD) methods is that neglecting serial correlation in outcomes may generate significant biases in estimated standard errors. To address this issue, our regression tables provide estimates of standard errors that are consistent in the presence of any correlation pattern within areas over time using again the generalized White method where clusters correspond to areas. Analysing similar DD specifications Bertrand, Duflo and Mullainathan (2004) finds that this strategy performs very well in finite samples when the number of clusters is larger than 20 (we have 23 areas). An even more conservative approach consists in aggregating time series information into pre-reform and post-reform observations and using these area-level aggregated outcomes as dependent variables $^{28}$. Comfortingly, this strategy provides us with estimates that are very similar to those in Table 3 and not less precise (see panel B of Appendix Table B4).

\section{Effect on Entry into Higher Education}

The School Leavers Survey (SLS) consists of a questionnaire sent to all secondary schools where they are asked to provide information on the secondary qualifications obtained by school leavers (GCSEs, A levels) and also on the post-secondary destination of these students

\footnotetext{
${ }^{28}$ See again Donald and Lang (2007) or Cameron and Miller (2010). This strategy is equivalent to regressing the differences between post-reform and pre-reform aggregated outcomes on the difference between post-reform and pre-reform aggregated elite schools' share using the likely intensity of the treatment $T_{i}$ as an instrumental variable.
} 
(higher education, employment, unemployment, training, unknown). By construction, the information on destinations is more speculative and less precise than the information on qualifications obtained before leaving $\operatorname{school}^{29}$. As mentioned in the guidance notes of the SLS, schools often have difficulties in coding the destinations of students who change residence or students who start to work during the summer after leaving school, but who may nonetheless enter into university at the beginning of the next academic year. With all these data limitations in mind, for each area and each cohort, we have constructed a measure of the number of students who have attended higher education after secondary school ${ }^{30}$ and we have analysed this destination outcome using exactly the same methods as those used previously to analyse secondary qualifications. As shown in Table 4, all three strategies suggest a positive effect of the reform on university attendance, even though the effect is less well estimated than the effect on qualifications. For example, model (3) shows that the increase in university attendance is stronger in areas where the increase in grammar school attendance is greater, suggesting that a $10 \%$ difference across areas in the increase in grammar school attendance between periods 1977-1978 and 1979-1980 generates a 5\% difference across areas in the increase in university attendance between the same period (.53 elasticity significant at the $1 \%$ level). While one might be concerned in principle that a big increase in the demand for university places might have led to constraints on the ability of the higher education system to absorb the new applicants, this does not apply in Northern Ireland. Students can apply to go to university in any part of the UK (as well as Northern Ireland) and thus there are many options. In a country the size of the UK, an increase in the supply of applicants of this magnitude is very unlikely to have caused difficulties.

\footnotetext{
${ }^{29}$ The guidance notes ask schools to use the "unknown" code in not more than $5 \%$ of the cases. Thus it is not possible to have an idea of the true "unknown" rate (i.e., the one that would emerge without coding constraints). ${ }^{30}$ Note that, in contrast, the SLS data cannot be used to construct for each cohort a measure of unemployment at entry into the labour market or unemployment at a given age.
} 


\section{Interpretation and Discussion.}

The interpretation of the overall improvement in exam performance in Northern Ireland is that it is the combination of three basic effects: the effect of attending grammar school on pupils who would otherwise have attended another secondary school; the effect of losing more able peers on students still entering non-grammar schools after the reform; the effect of having less able peers on students who would have entered a grammar school even in the absence of the reform. It is not possible to point identify the specific contribution of each of these effects. Nonetheless, it is possible to provide plausible lower bounds by examining the impact of the reform separately for elite and non-elite schools.

\section{A Bounds to Contextual Effects}

To be specific, the reform defines three different ability groups $(g=A, B$ and $C$ ). Firstly, there is a group of relatively high ability pupils $(g=A)$ who would have entered grammar school even in the absence of the reform. The impact of the reform on this group amounts to the effect of having a group of peers with relatively low average ability compared to what would have been the case in the absence of the reform. Secondly, there is a group of mid-ability pupils $(g=B)$ who attend grammar school after the reform, but who would have attended another secondary school had the reform not taken place. The effect of the reform on these pupils is potentially very important since such pupils are exposed to a radically different school context than what they would have faced in the absence of the reform. Finally, there is a group of relatively low ability pupils $(g=C)$ who attend other secondary schools both before and after the reform. They are affected by the change in the composition of these schools. Specifically, they have lost their best peers ( $\operatorname{group} B)$ because of the reform.

Using these notations, elite schools include group A only before the reform, but are composed of groups A + B after the reform. In such a case, the variation in elite schools' 
average outcomes after the reform reflects (1) the fact that the average ability of pupils has declined in these school (because of the inclusion of group B) (2) the fact that the performance of group A may itself have been affected by this new group of peers. In other words, the change in elite schools' average outcomes is a mix between a potentially negative composition effect and more ambiguous peer effects on high ability pupils.

Hence, the impact of the reform on the average outcomes in elite schools does not point identify peers' effect on group $A$, but provides a lower bound for this contextual effect. A more formal presentation of this argument is given in Appendix C.

Similarly, the variation in average outcomes in non-elite schools after the reform is a mix between (1) the effect of the change in peers' composition on the group $C$ of low-ability pupils and (2) the potentially negative composition effect due to the loss of group $B$, i.e., a group of pupils with higher ability than group $C$. Hence, the effect of the reform on the average outcomes in non-elite schools does not point identify peers' effect on group $C$, but provides a plausible lower bound for this effect. In the next sub-section, we provide a separate empirical evaluation of the effects of the reform on grammar and non-grammar schools which we interpret as lower bounds for the contextual effects that have affected top and bottom ability students after the reform.

\section{B Separate Effects for Grammar and Non Grammar Schools}

The panel A of Table 5 shows regressions of the number of successful students in each school type (and of the total number of students in each school type) on a "reform on" dummy using the same set of control variables as those used in Table 1: cohort size $\left(S_{i, c}\right)$ and a spline function of cohort with a knot at the reform date. Column (1) confirms that the size of elite schools increased by about $12.4 \%$ just after cohort 1978 . This timing corresponds to the inflow of relatively low ability students generated by the reform in these schools. 
Interestingly, Column (2) reveals that the reform was followed by an even larger shift $(+13.5 \%)$ in the number of successful students at age 16 in these schools. Overall, success has increased at about the same rate as entry to grammar schools which is consistent with the assumption that new students in elite schools have not generated negative externalities (in spite of their relatively low ability) and have in fact strongly benefited from their new highability peers ${ }^{31}$.

Another possible explanation for the relatively good performance of grammar schools after the reform is that they have benefited from economies of scale, i.e. their increase in size after the reform has had, as such, a positive effect on their students' average outcomes. To separate the effect of change in size and the effect of change in composition, we have regressed the number of successful students in grammar schools on both the proportion of the total population of students selected to a grammar school (composition effect) and the absolute number of students selected in grammar school (size effect) using the "reform on" dummy and the cohort size $\left(S_{i, c}\right)$ as instrumental variables. This analysis (available on request) confirms that change in composition has, as such, no significant effect on outcomes, whereas the elasticity of the number of successful students for the number of enrolled students is close to 1 (and not significantly different from 1). It confirms that there are no significant economies of scale in these schools and that they have benefited from unambiguously nonnegative contextual effects after the reform.

The picture is somewhat different in non-elite schools. Column (3) confirms that they underwent a significant negative shift in size just after the reform (-4.4\%). But column (4) reveals that it was accompanied by an even more negative shift in the number of successful students at age 16 in these schools $(-11.3 \%)$, although the difference between the two estimates is not statistically different. Overall, success seems to have declined more rapidly

\footnotetext{
${ }^{31}$ The mechanism may be direct interaction with high quality peers or indirect effects because of teachers' reaction to having a good intake (leading to more rigorous standards for example).
} 
than attendance in non-elite schools. Hence, we are a situation where the sign of the contextual effect of the reform on low ability students is ambiguous. The decline in average outcomes observed in non-grammar schools may simply reflect the decline in the average level of ability of students after the reform in these schools. However, it may also partly reflect the fact that students in these schools have lost their best peers after the reform.

As a robustness check, panel $\mathrm{B}$ of Table 5 replicates the difference-in-differences analysis separately for each school type, using the same set of explanatory variables as those used in Table 3: an interaction between treatment intensity $T_{i}$ and a "reform on" dummy, cohort size, area and cohort fixed effects. To start with, Columns 1 and 2 in panel B show that an increase in $T_{i}$ in an area is associated with an increase in the number of successful students in grammar schools after the reform which is almost as large as the increase in the size of grammar schools in this area. By contrast, Columns 3 and 4 show that an increase in treatment intensity $T_{i}$ in an area is associated with a decline in the number of successful students in nongrammar schools after the reform which is stronger than the decline in non-grammar schools' size in this area. These findings confirm that the reform has been associated with non-negative contextual effects in elite schools, whereas the sign of contextual effects in non-elite schools is ambiguous.

\section{Conclusion}

The tracking of students by ability into different schools is a common phenomenon in developed countries. Also, reforms increasing the size of the more selective tracks have occurred in many countries over recent decades. The effects of such 'de-tracking' policies are difficult to identify because they often happen at the same time as other educational reforms. Thus, there is little reliable evidence with which to debate the consequences of such controversial reforms. In this context, the reform examined in this paper is particularly 
interesting: there was a large increase in the number of pupils admitted to the elite track whereas, in other respects, the educational system remained unchanged. Analysing the discontinuity in the distribution of educational outcomes across cohorts and local areas, we show that the net effect of the 'de-tracking' reform was a very significant increase in examination results at the end of compulsory schooling (i.e. GCSEs, age 16) and 'high school' (i.e. A-levels, age 18). According to our basic estimates, a $10 \%$ increase in the proportion of students selected in elite school at age 11 in an area is followed by an increase of about $4 \%$ in the number of students who pass national examinations at age 16 and an increase of about $7 \%$ in the number of students who pass national examinations at age 18 . These effects encompass not only the direct effect of attending grammar school for the marginal entrants, but also the indirect effect arising from the change in school context in both elite and non-elite schools. Overall, this paper provides an unambiguous piece of evidence that widening access to the more academic track can generate very positive net effects.

\section{References}

Aavik, A., K. Salvanes and K. Vaage, (2010), "Measuring Heterogeneity in the Returns to Education in Norway Using An Educational Reform", European Economic Review, 54 (4):483-500.

Altonji, J., T. Elder and C. Taber, (2005), "Selection on Observed and Unobserved Variables: Assessing the Effectiveness of Catholic Schools", Journal of Political Economy,113(1):151184.

Atkinson, A., P.Gregg, and B.McConnell, (2005), "The Result of 11 Plus Selection: An Investigation into Equity and Efficiency of Outcomes for Pupils in Selective LEAs", Mimeo, Leverhulme Centre for Market and Public Organisation, University of Bristol.

Betts, J.R., and J.L. Shkolnik, (1999), "The Effects of Ability Grouping on Student Math Achievement and Resource Allocation in Secondary Schools", Economics of Education Review, 19: 1-15.

Bertrand, M., E. Duflo and S. Mullainathan, (2004), "How Much Should We Trust Differences-in-Differences Estimates", Quarterly Journal of Economics, 99:249-275 
Blundell, R., L. Dearden and B. Sianesi, (2005), "Evaluating the Effect of Education on Earnings: Models, Methods and Results from the National Child Development Survey", Journal of the Royal Statistical Society. A. 168(3): 473-512.

Bundesministerium für Bildung und Forschung, (2008), Bildung in Deutschland 2008.

Cameron, A.C., and D.L. Miller, (2010), "Robust Inference with Clustered Data", University of California at Davis, Working Papers No. 10-7.

Clark, D., (2010), "Selective Schools and Academic Achievement", The B.E. Journal of Economic Analysis \& Policy, 10(1). Advances. Art. 9.

Cullen, J., B. Jacob, and S. Levitt (2006), "The Effect of School Choice on Student Outcomes: Evidence from Randomized Lotteries”, Econometrica 74(5): 1191-1230.

Department of Education, (1986), Discussion Paper on Intake Controls and Parental Choice in the Secondary School Sector in Northern Ireland. Department of Education. Northern Ireland.

Donald, S.G. and K. Lang, (2007), "Inference with Difference-in-Differences and Other Panel Data”, Review of Economics and Statistics, 80: 549-560.

Duflo, Esther, Dupas Pascaline and Michael Kremer, (2008), "Peer Effects, Teachers Incentives and the Impact of Tracking: Evidence from a Randomized Evaluation in Kenya", NBER Working Paper No. 14475, American Economic Review, forthcoming.

Figlio, D.N., and M.E. Page, (2002), "School Choice and the Distributional Effects of Ability Tracking: Does Separation Increase Inequality?", Journal of Urban Economics, 51, 497-514.

Galindo-Rueda, F., and A.Vignoles, (2004), "The Heterogeneous Effect of Selection in Secondary Schools: Understanding the Changing Role of Ability", Institute for the Study of Labor (IZA) Discussion Paper 1245. Bonn, Germany.

Gallagher, T., and A. Smith, (2000), "The Effects of the Selective System of Secondary Education in Northern Ireland", Report to the Department of Education, Northern Ireland.

Gurgand, Marc and Eric Maurin (2006), "Démocratisation de l'enseignement secondaire et inégalités salariales en France", Annales, Histoire, Sciences Sociales, 4, 845-859.

Hanushek, E.A. and L. Wößmann (2006), "Does Educational Tracking Affect Performance and Inequality? Differences-in-Differences Evidence Across Countries", Economic Journal 116, C363-C76.

Harland, J., H. Moor, K. Kinder and M. Ashworth (2002), "Is the Curriculum Working? The Key Stage 3 Phase of the Northern Ireland Curriculum Cohort Study", National Foundation for Educational Research, Slough.

Kerckhoff, A.C., K. Fogelman, D.Crook and D.Reeder, (1996), "Going Comprehensive in England and Wales", The Woburn Press. 
Manning A. and S. Pischke, (2006),"Comprehensive versus Selective Schooling in England and Wales: What Do We Know?", IZA DP No. 2072.

Maurin, E., and S. McNally, (2008), "Vive la revolution! Long term returns of 1968 to the angry students", Journal of Labor Economics, 26 (1), pp:1-33.

Mülhenweg, A. and P. Puhani, (2010),'The Evolution of School Entry Age Effect in a School Tracking System”, Journal of Human Resources, Vol. 45 (2), pp:407-438.

McIntosh, S., (2006), "Further Analysis of the Returns to Academic and Vocational Qualifications", Oxford Bulletin of Economics and Statistics, Vol 68: 225-251.

Meghir, C., and M. Palme, (2005), "Educational Reform, Ability and Family Backround", American Economic Review, Vol. 95, No. 1, pp. 414-424.

Morgan, V., (1993), "Gender and the Common Curriculum", in R. Osborne, R. Cormack and A. Gallagher (eds)., After the Reforms: Education and Policy in Northern Ireland, Avebury.

Northern Ireland Economic Council (1995), "Reforming the Educational System in Northern Ireland", Occasional Paper 1, January.

Pekkarinen, T., R. Uusitalo and S. Pekkala, (2009), "Education Policy and Intergenerational Income Mobility: Evidence from the Finnish Comprehensive School Reform", Journal of Public Economics, 93, (965-973).

Sutherland, A., (1993), “The Transfer Procedure Reformed?” in R. Osborne, R. Cormack and A. Gallagher (eds), After the Reforms: Education and Policy in Northern Ireland, Avebury.

Waldinger, F., (2006), ”Does Tracking Affect the Importance of Family Background on Students' Test Score", Unpublished Manuscript, London School of Economics. 
Figure 1: Number of Entrants to Grammar School in Northern-Ireland, by Year of Birth.

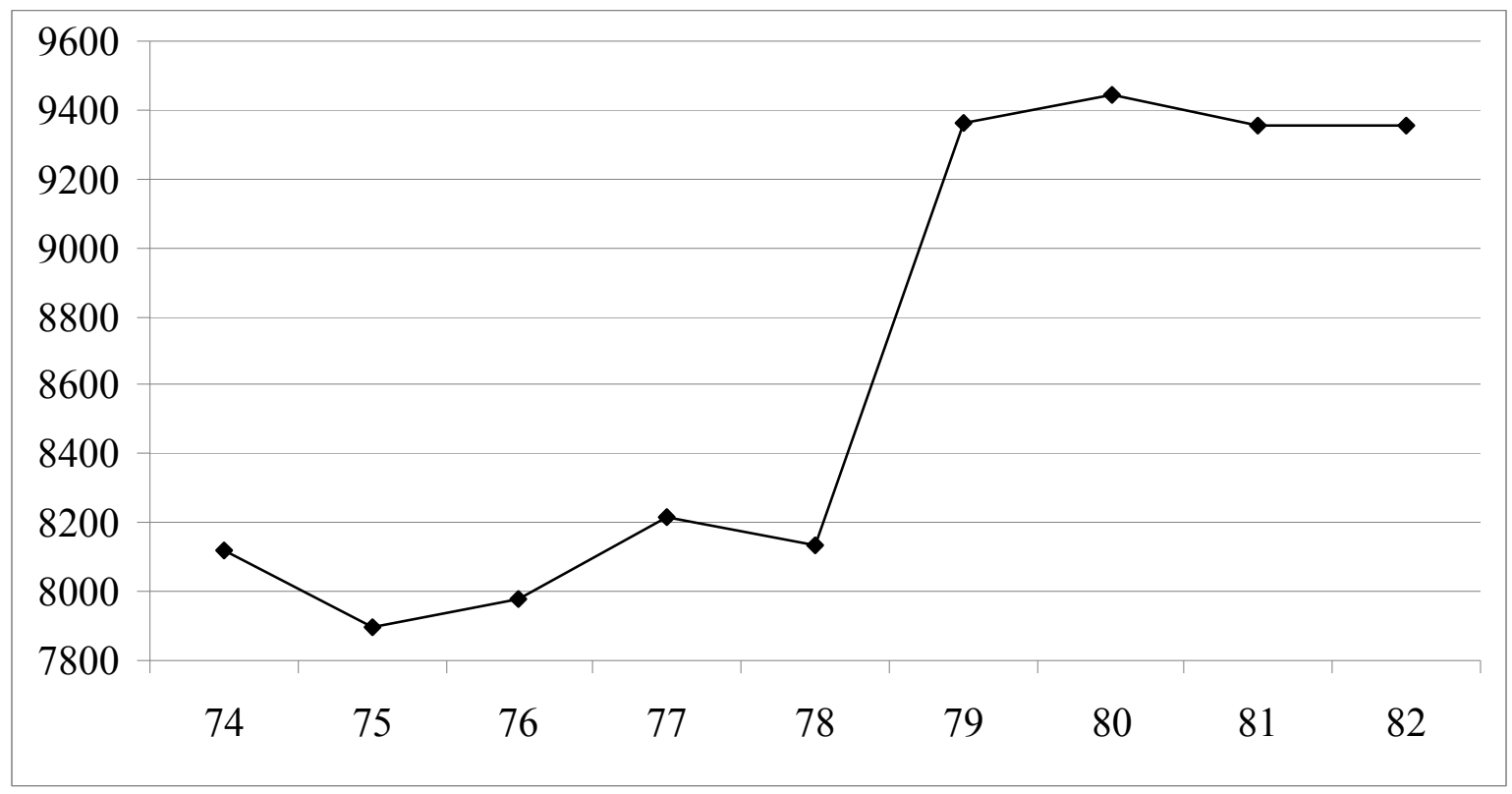

Figure 2: Evolution of Cohort Size and Number of Entrants to Grammar School, by Year of Birth (1974=1).

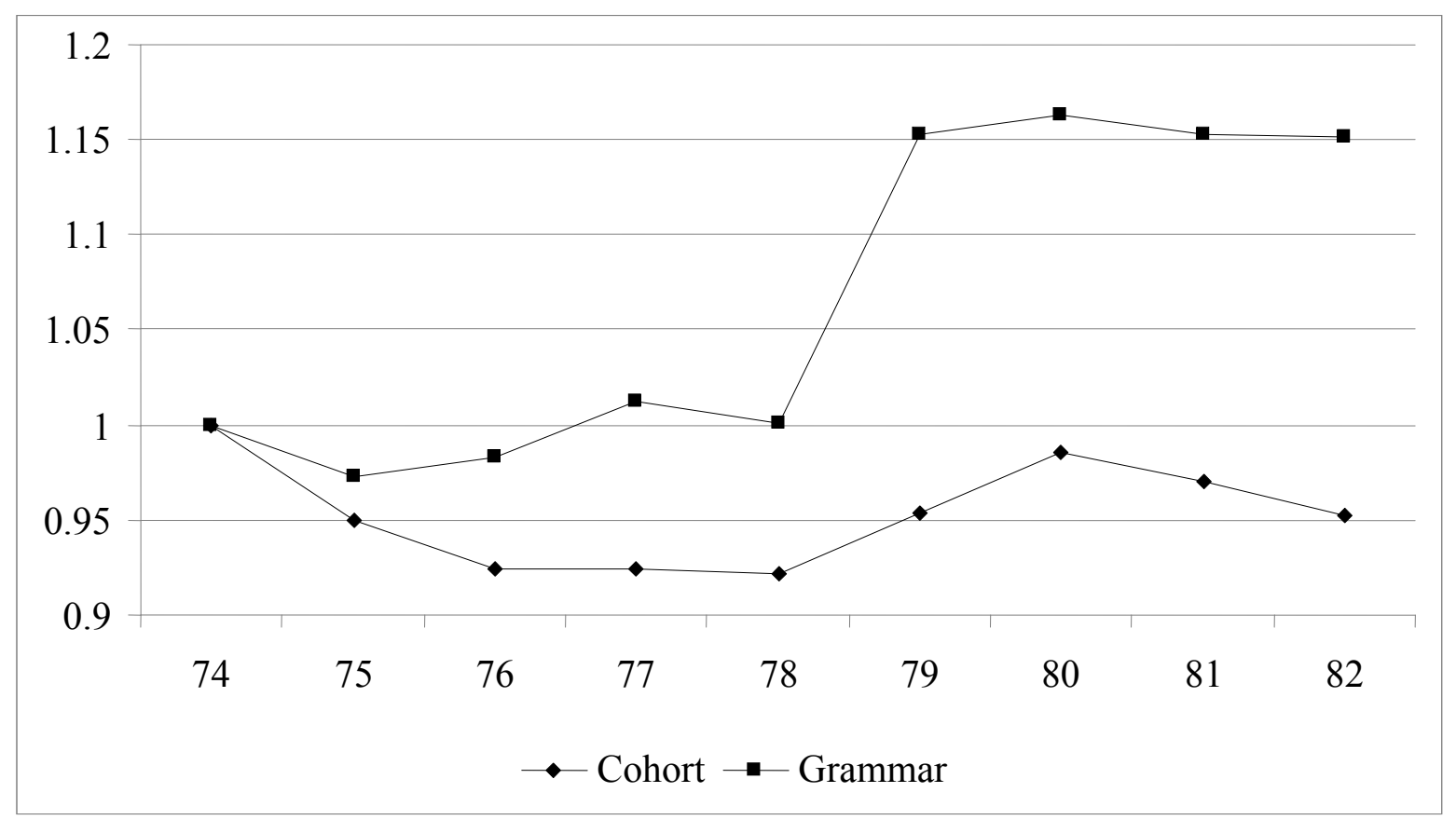


Figure 3: Educational Outcomes in England, by Year of Birth.

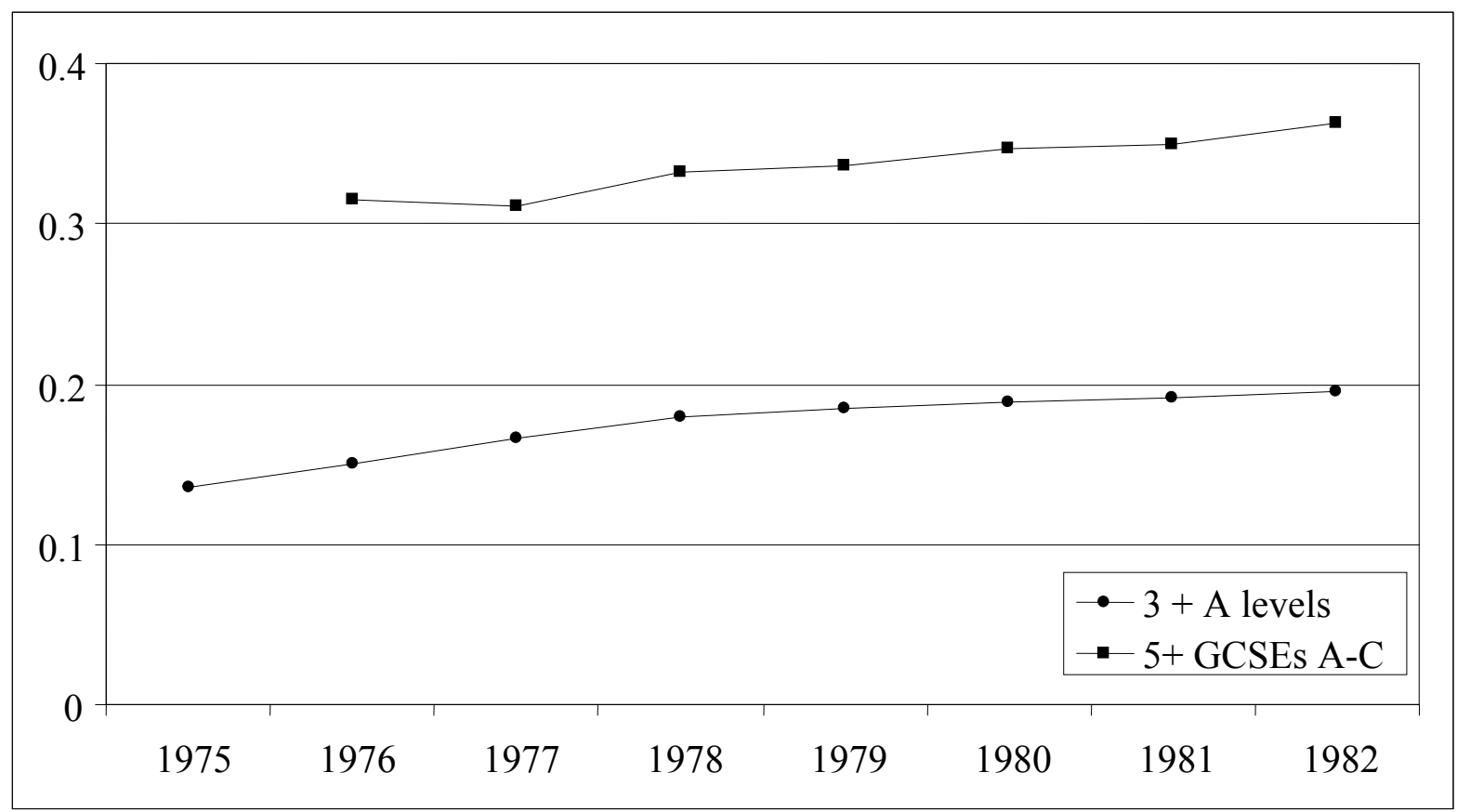

Figure 4: Variation across Cohorts in the (log) Number of Students Attending Elite Schools in Northern Ireland.

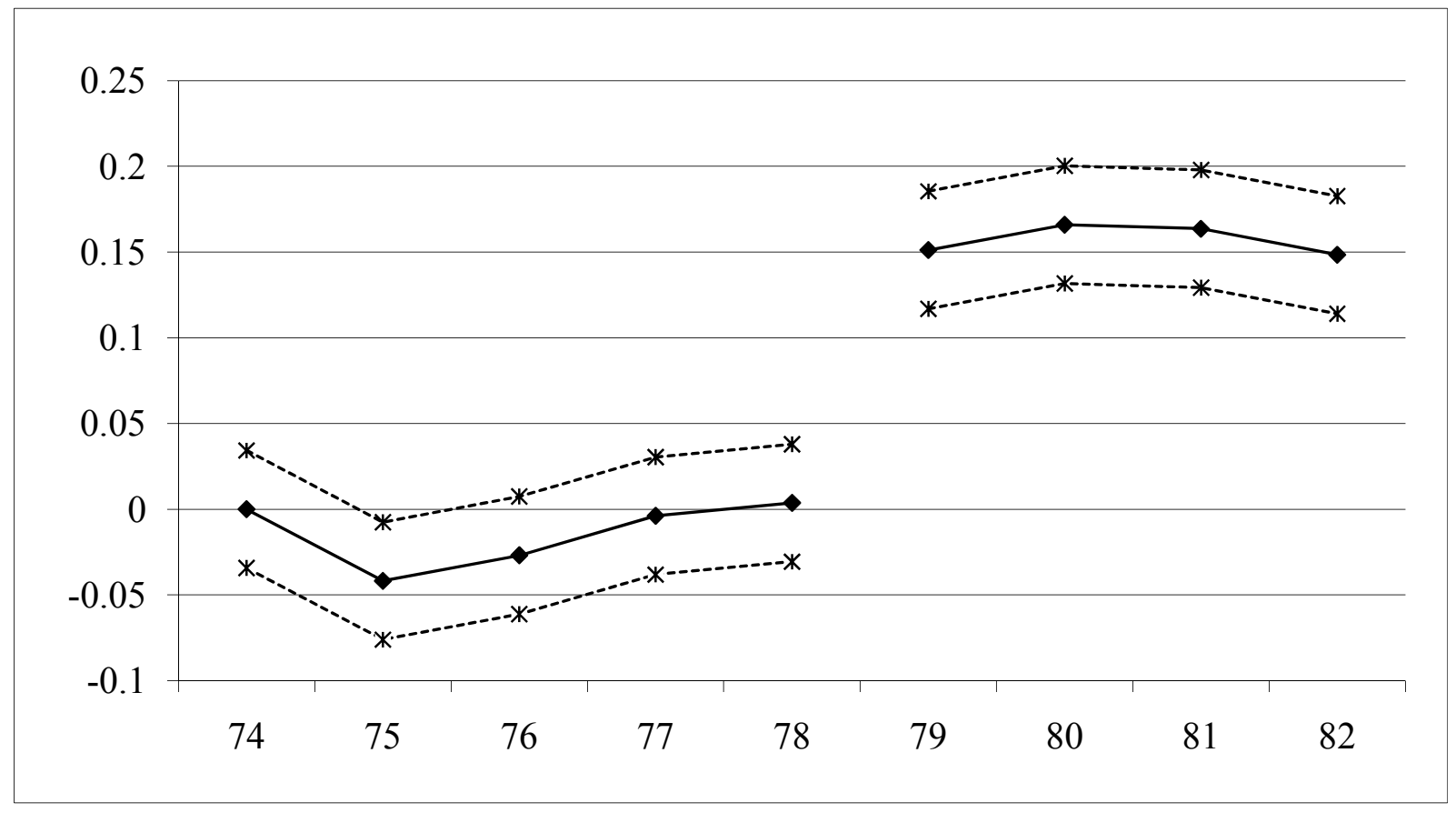

Note: Using the area-level data, the graph shows the change across cohorts in the (log) number of students attending grammar schools (cohort 1974 taken as a reference). The average number of students attending elite schools is $15 \%$ higher in cohort 1979 than in cohort 1978. Dotted lines show confidence intervals. 
Figure 5: Variation across Cohorts in the (log) Number of Successful Students at Age 16.

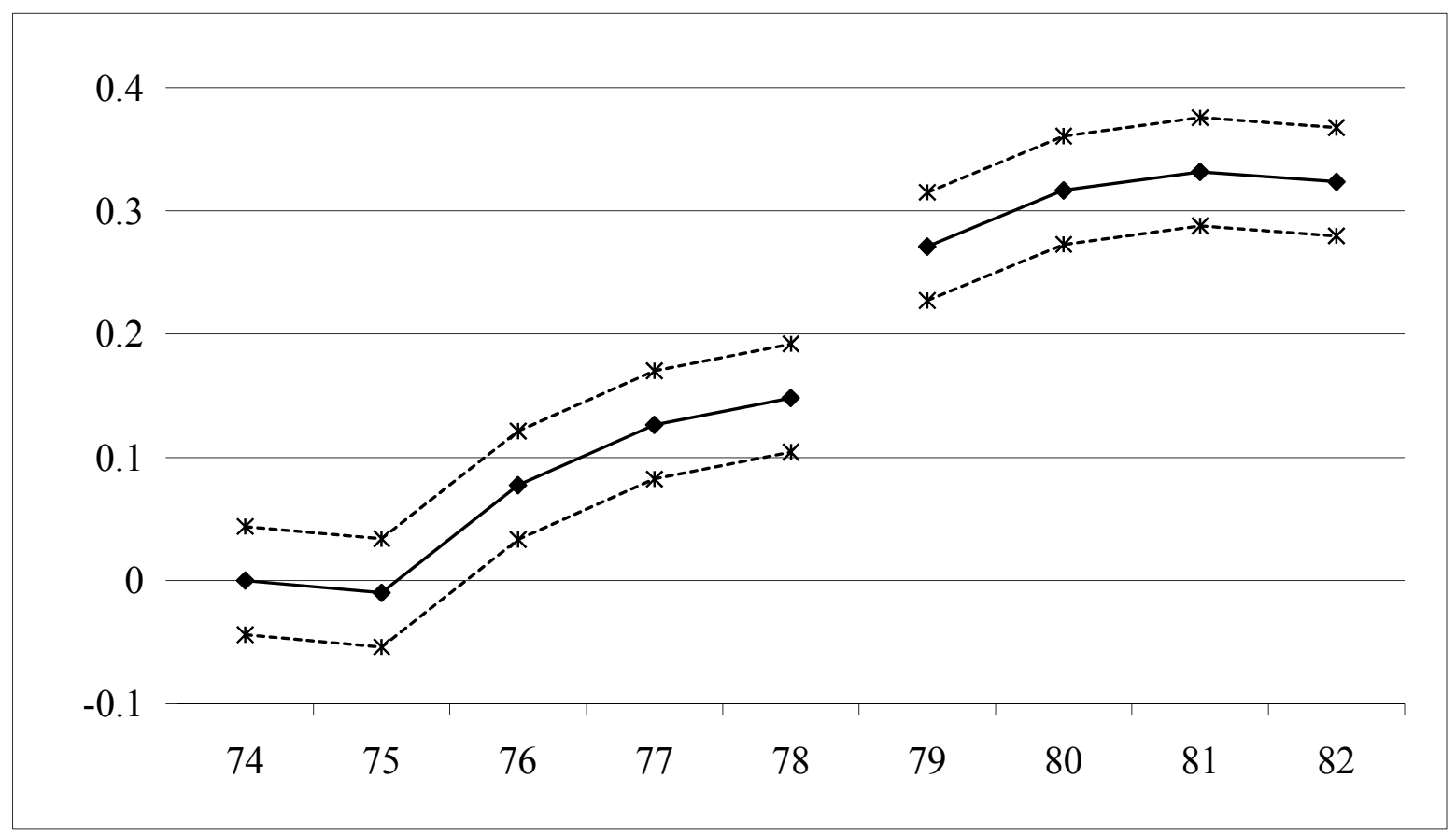

Note: Using area-level data, the graph shows the change across cohorts in the average of the (log) number of students obtaining 5 or more GCSEs at grades A*-C (cohort 1974 taken as a reference). Dotted lines show confidence intervals.

Figure 6: Variation across Cohorts in the $(\log )$ Number of Successful Students at age 18.

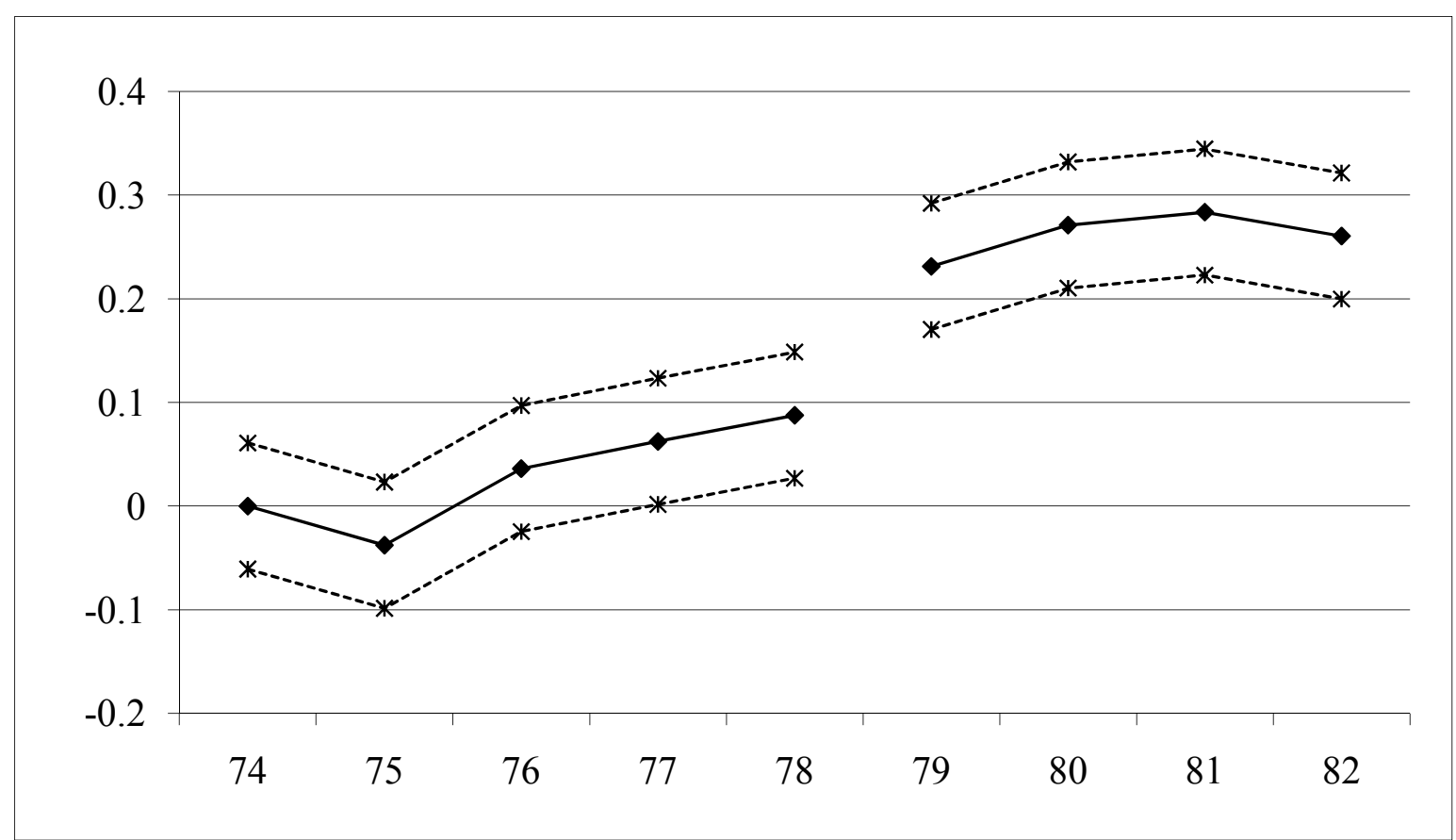

Note: Using the area-level data, the graph shows the change across cohorts in the average of the (log) number of students obtaining 3 or more A levels (cohort 1974 taken as a reference). Dotted lines show confidence intervals. 
Figure 7: Variation in the Proportion of Successful Students at Age 16 and Variation in Elite School Attendance Between Pre-Reform and Post-Reform Cohorts.

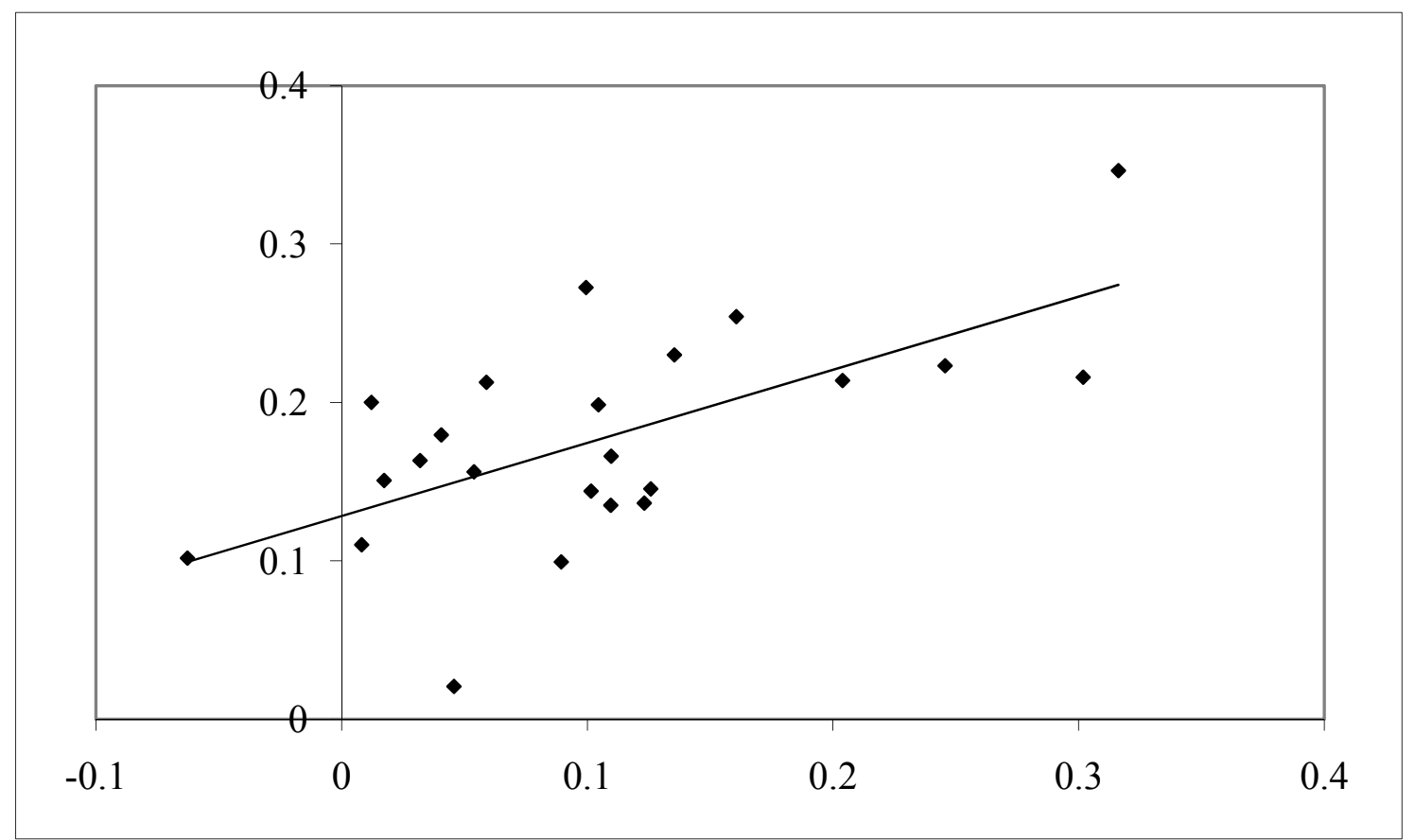

Note: for each local area, the X-axis corresponds to variation in the log proportion attending elite schools between cohorts 1974-1978 and cohorts 1979-1982, whereas the Y-axis corresponds to variation in the log proportion of successful students at age 16.

Figure 8: Variation in the Proportion of Successful Students at Age 18 and Variation in Elite School Attendance Between Pre-Reform and Post-Reform Cohorts.

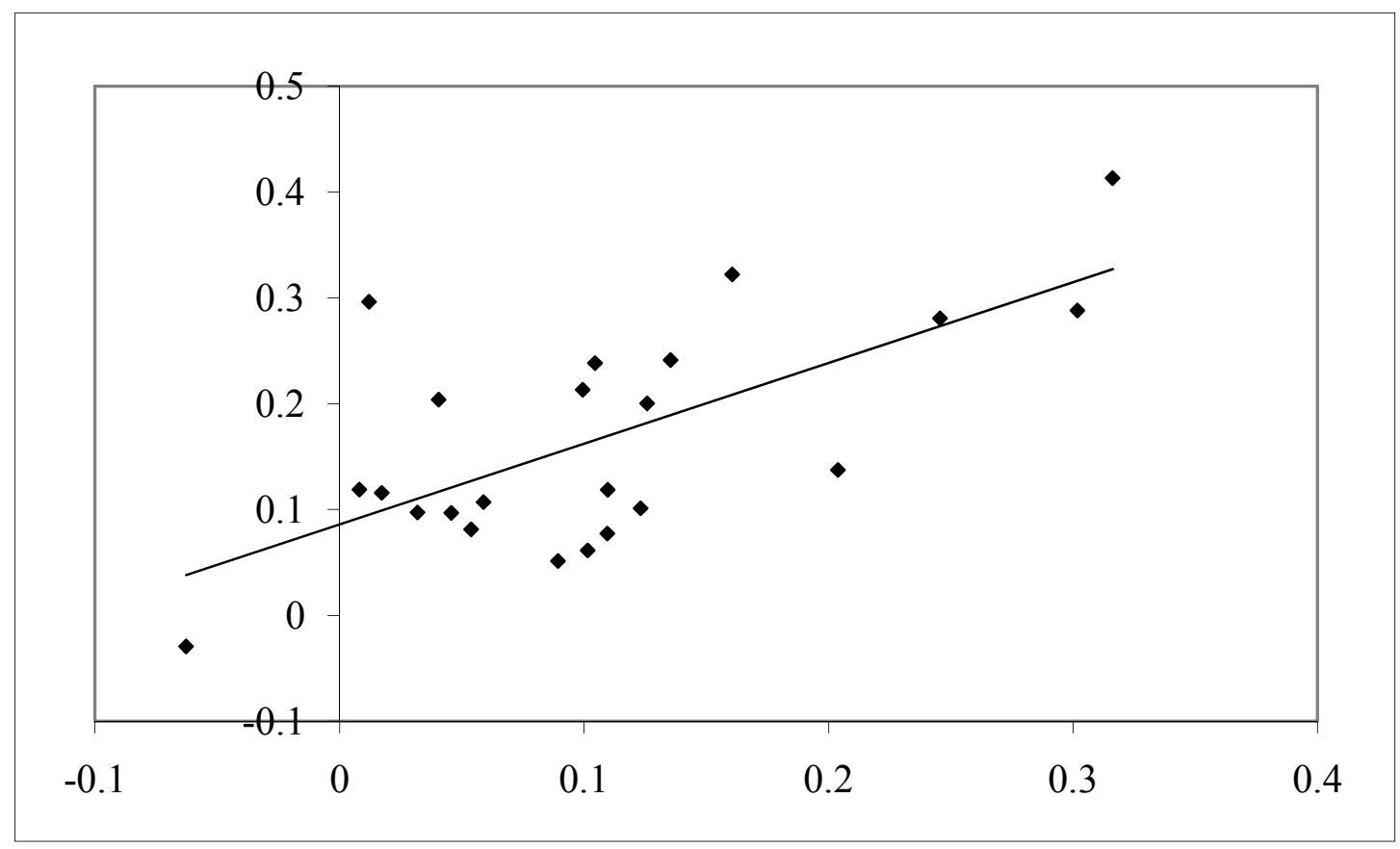

Note: for each local area, the X-axis corresponds to variation in the log proportion attending elite schools between cohorts 1974-1978 and cohorts 1979-1982, whereas the Y-axis corresponds to variation in the log proportion of successful students at age 18 . 
Table 1: Effect of the Proportion Attending Elite School at Age 11 on Educational Outcomes at Age 16 and 18: An Evaluation Using the Discontinuity in Grammar School Attendance at the Reform Date.

\begin{tabular}{|c|c|c|c|c|c|c|c|}
\hline & \multirow{2}{*}{$\begin{array}{c}\text { First- } \\
\text { stage } \\
\text { Prop. Elite } \\
\left(G_{i c}\right) \\
(1)\end{array}$} & \multicolumn{2}{|c|}{ Reduced form } & \multicolumn{2}{|c|}{ IV } & \multicolumn{2}{|c|}{ OLS } \\
\hline & & $\begin{array}{c}\text { Number } \\
\text { Success. } \\
\text { Age } 16 \\
(2)\end{array}$ & $\begin{array}{c}\text { Number } \\
\text { Success. } \\
\text { Age } 18 \\
(3)\end{array}$ & $\begin{array}{c}\text { Number } \\
\text { Success. } \\
\text { Age } 16 \\
(4)\end{array}$ & $\begin{array}{c}\text { Number } \\
\text { Success. } \\
\text { Age } 18 \\
(5)\end{array}$ & $\begin{array}{c}\text { Number } \\
\text { Success. } \\
\text { Age } 16 \\
(6)\end{array}$ & $\begin{array}{c}\text { Number } \\
\text { Success. } \\
\text { Age } 18 \\
(7)\end{array}$ \\
\hline $\begin{array}{l}\text { Prop. Elite } \\
\left(G_{i c}\right)\end{array}$ & - & - & - & $\begin{array}{l}.405 \\
(.137)\end{array}$ & $\begin{array}{c}.752 \\
(.100)\end{array}$ & $\begin{array}{c}.405 \\
(.043)\end{array}$ & $\begin{array}{l}.715 \\
(.092)\end{array}$ \\
\hline $\begin{array}{l}\text { Reform on } \\
(c>1978)\end{array}$ & $\begin{array}{l}.124 \\
(.010)\end{array}$ & $\begin{array}{l}.050 \\
(.018)\end{array}$ & $\begin{array}{l}.093 \\
(.012)\end{array}$ & - & - & - & - \\
\hline $\begin{array}{l}\text { Year of birth } \\
\text { (c) }\end{array}$ & $\begin{array}{l}.011 \\
(.002)\end{array}$ & $\begin{array}{l}.054 \\
(.005)\end{array}$ & $\begin{array}{l}.037 \\
(.003)\end{array}$ & $\begin{array}{l}.049 \\
(.007)\end{array}$ & $\begin{array}{l}.029 \\
(.004)\end{array}$ & $\begin{array}{l}.049 \\
(.004)\end{array}$ & $\begin{array}{l}.030 \\
(.002)\end{array}$ \\
\hline $\begin{array}{l}(c-1978) \mathrm{x} \\
(c>1978)\end{array}$ & $\begin{array}{l}-.014 \\
(.002)\end{array}$ & $\begin{array}{l}-.038 \\
(.005)\end{array}$ & $\begin{array}{l}-.029 \\
(.003)\end{array}$ & $\begin{array}{l}-.033 \\
(.007)\end{array}$ & $\begin{array}{l}-.019 \\
(.004)\end{array}$ & $\begin{array}{l}-.033 \\
(.007)\end{array}$ & $\begin{array}{l}-.019 \\
(.004)\end{array}$ \\
\hline $\begin{array}{l}\text { Total number } \\
\text { students }\left(S_{i c}\right)\end{array}$ & $\begin{array}{l}-.539 \\
(.051)\end{array}$ & $\begin{array}{c}.712 \\
(.057)\end{array}$ & $\begin{array}{c}.664 \\
(.065)\end{array}$ & $\begin{array}{c}.930 \\
(.072)\end{array}$ & $\begin{array}{l}1.069 \\
(.055)\end{array}$ & $\begin{array}{l}.930 \\
(.049)\end{array}$ & $\begin{array}{l}1.055 \\
(.075)\end{array}$ \\
\hline$N$ & 207 & 207 & 207 & 207 & 207 & 207 & 207 \\
\hline $\begin{array}{l}\text { Note: Column (1 } \\
\text { "reform on" dum } \\
\text { control variables } \\
\text { students at age } 1 \\
\text { IV regressions }\end{array}$ & $\begin{array}{l}\text { a. } 2 \text { in the } \\
\text { or } 18 \text { on the } \\
\text { ing "reforr }\end{array}$ & $\begin{array}{l}\text { t). Colum } \\
\text { one set of } \\
\text { " as an }\end{array}$ & $\begin{array}{l}\text { g) propo } \\
\text { a spline } \\
\text { and (3) } \\
\text { endent va } \\
\text { rumental }\end{array}$ & $\begin{array}{l}\text { of studen } \\
\text { tion of ye } \\
\text { the regre } \\
\text { es. Colum } \\
\text { ble) whe }\end{array}$ & $\begin{array}{l}\text { Itending gra } \\
f \text { birth and } \\
n \text { of the (lo } \\
\text { (4) and (5) } \\
\text { Columns }\end{array}$ & $\begin{array}{l}\text { mmar schoo } \\
23 \text { area fixe } \\
\text { g) number of } \\
\text { show the cor } \\
\text { (6) and (7) }\end{array}$ & $\begin{array}{l}\left(G_{i c}\right) \text { on a } \\
\text { effects as } \\
\text { successful } \\
\text { esponding } \\
\text { show the } \\
5 \text { or more }\end{array}$ \\
\hline
\end{tabular}


Table 2: The Effect of the Variation in Elite School Attendance at Age 11 on the Variation in Average Educational Outcomes Across Pre-Reform and Post-Reform Cohorts.

Remark: $23-2=21$ degrees of freedom, so significant at $5 \%$ if $t>T(0.975 ; 6)=2.080$, and at $10 \%$ if if $t>T(0.95 ; 6)=1.721)$

$$
\begin{array}{ccc}
\text { Dependent variable : } \mathrm{Y}_{i, \text { after }}-\mathrm{Y}_{i, \text { before }} & \left(\mathrm{S}_{i, \text { after }}-\mathrm{S}_{i, \text { before }}\right) \\
\text { at age } 16 & \text { at age } 18 & \\
(5 \text { or }+ \text { GCSEs A*-C }) & (3 \text { or }+ \text { A Levels }) & (3) \\
(1) & (2) & (3)
\end{array}
$$

Panel A: 1974-1982

$\begin{array}{cccc}\left(\mathrm{G}_{i, \text { after }}-\mathrm{G}_{i, \text { before }}\right) & .461(.165) & .752(.209) & -.269(.153) \\ \left(\mathrm{S}_{i, \text { after }}-\mathrm{S}_{i, \text { before }}\right) & 1.001(.209) & .962(.285) & - \\ N & 23 & 23 & 23\end{array}$

Panel B: 1977-1980

$\begin{array}{cccc}\left(\mathrm{G}_{i, \text { after }}-\mathrm{G}_{i, \text { before }}\right) & .367(.116) & .615(.109) & -.047(.113) \\ \left(\mathrm{S}_{i, \text { after }}-\mathrm{S}_{i, \text { before }}\right) & 1.304(.345) & .829(.283) & - \\ N & 23 & 23 & 23\end{array}$

Panel C:

1974-1976/1979-1982

$\begin{array}{cccc}\left(\mathrm{G}_{i, \text { after }}-\mathrm{G}_{i, \text { before }}\right) & .423(.177) & .807(.319) & -.358(.142) \\ \left(\mathrm{S}_{i, \text { after }}-\mathrm{S}_{i, \text { before }}\right) & .895(.174) & 1.119(.322) & -\end{array}$

\section{$N$ \\ 23 \\ 23 \\ 23}

Notes: Columns (1) and (2) show the regression of the difference in average (log) number of successful students at age 16 and 18 between pre-reform and post-reform period (denoted $Y_{i, \text { after }}-Y_{i, \text { before }}$ ) on the difference in average $(\log )$ proportion of students attending grammar schools $\left(\mathrm{G}_{i, \text { after }}-\mathrm{G}_{i, \text { before }}\right)$ and the difference in average $(\log )$ cohort size $\left(\mathrm{S}_{i, \text { after }}-\mathrm{S}_{i, \text { before }}\right)$. Column (3) shows the regression of the difference in average (log) cohort size between pre-reform and post-reform cohort on the difference in average (log) proportion attending grammar schools. In Panel A, pre-reform cohorts=1974-1978 and post-reform cohorts=1979-1982. In panel B, pre-reform cohorts $=1977-1978$ and post-reform cohorts $=1979-1980$. In panel C, pre-reform cohorts=1974-1976 and postreform cohorts $=1979-1980$. Standard errors are in parentheses. 
Table 3: Effect of the Proportion Attending Elite School at Age 11 on Educational Outcomes at Age 16 and 18: An Evaluation Using the Pre-reform Variation in the Number of Students attending Elite Schools
First-stage
Reduced-form
IV

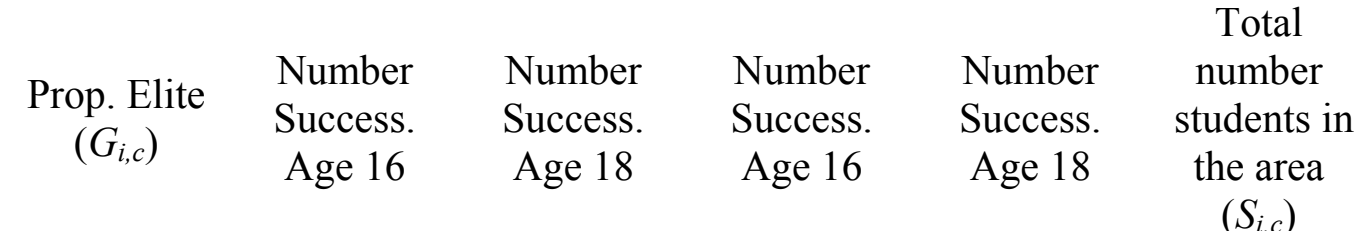

\section{(1)}

(2)

Prop. Elite

$\left(G_{i, c}\right)$

Reform on $\mathrm{x}$

$T_{i}$

Total number

students in

the area $\left(S_{i, c}\right)$

(.686)

$-.491$

(.127)
(3)

(4)

.505

(.262)

1.215

(.833)

.718

(.521)

.783

(.132)

.683

(.212)

1.031

(.175)

1.103

(.246)
(6)

.854

(.401)

207

207

207

207

207

207

Note: Column (1) shows the regression of the $(\log )$ proportion of students attending grammar school $\left(G_{i, c}\right)$ on a variable interacting a "reform on" dummy and intensity of treatment $T_{i}$ using (log) cohort size $\left(S_{i, c}\right)$, 9 cohort fixed effects and 23 area fixed effects as control variables. Columns (2) and (3) shows the regression of the (log) number of successful students at age 16 or 18 on the same set of independent variables. Columns (4) and (5) shows the corresponding IV regressions (where the interaction variable is used as instrument). Finally, Columns (6) shows the regression of $(\log )$ cohort size on the interaction variable, cohort fixed effects and area fixed effects. The educational outcome at age 16 is the $(\log )$ number of students obtaining 5 or more grades at $A^{*}$-C in the GCSE examination. At age 18, it is the $(\log )$ number of students obtaining 3 or more A-levels. Standard errors are in parentheses. 
Table 4: Effect of the Reform on Entry into Higher Education

Simple difference

Difference-in-differences

\begin{tabular}{|c|c|c|c|c|c|c|}
\hline & $\begin{array}{l}\text { Red.Form } \\
\text { (1) }\end{array}$ & $\begin{array}{l}\text { IV } \\
(2)\end{array}$ & $\begin{array}{l}\text { OLS } \\
(3)\end{array}$ & $\begin{array}{l}\text { Red.Form } \\
\text { (4) }\end{array}$ & $\begin{array}{l}\text { IV } \\
(5)\end{array}$ & $\begin{array}{c}\text { OLS } \\
(6)\end{array}$ \\
\hline Prop. Elite $\left(G_{i c}\right)$ & - & $\begin{array}{l}.368 \\
(.090)\end{array}$ & $\begin{array}{l}.627 \\
(.106)\end{array}$ & - & $\begin{array}{l}.670 \\
(.511)\end{array}$ & $\begin{array}{c}.690 \\
(.098)\end{array}$ \\
\hline Reform on x $T_{i}$ & - & - & - & $\begin{array}{c}.953 \\
(.879)\end{array}$ & - & - \\
\hline Reform on & $\begin{array}{l}.046 \\
(.010)\end{array}$ & - & - & - & - & - \\
\hline$N$ & 207 & 207 & 207 & 207 & 207 & 207 \\
\hline & \multicolumn{2}{|c|}{$\begin{array}{c}\text { Panel } A \\
\text { (cohorts 1974-1982) } \\
(7)\end{array}$} & \multicolumn{2}{|c|}{$\begin{array}{c}\text { Panel B } \\
\text { (cohorts 1977-1980) } \\
\text { (8) }\end{array}$} & \multicolumn{2}{|c|}{$\begin{array}{c}\text { Panel C } \\
\text { (cohorts 1974/1976- } \\
\text { 1979/1982) } \\
(9)\end{array}$} \\
\hline$\left(\mathrm{G}_{i, \text { after }}-\mathrm{G}_{i, \text { before }}\right)$ & & & & & \multicolumn{2}{|c|}{$\begin{array}{c}.842 \\
(.296)\end{array}$} \\
\hline$\left(\mathrm{S}_{i, \text { after }}-\mathrm{S}_{i, \text { before }}\right)$ & \multicolumn{2}{|c|}{$\begin{array}{l}1.401 \\
(.315)\end{array}$} & \multicolumn{2}{|c|}{$\begin{array}{l}1.242 \\
(.275)\end{array}$} & \multicolumn{2}{|c|}{$\begin{array}{l}1.525 \\
(.359)\end{array}$} \\
\hline$N$ & \multicolumn{2}{|c|}{23} & \multicolumn{2}{|c|}{23} & \multicolumn{2}{|c|}{23} \\
\hline
\end{tabular}

Note: Models (1), (2) and (3) show the results of replicating the reduced-form, IV and OLS regressions of Table 1 using the $(\log )$ number of students entering higher education as dependent variable rather than the $(\log )$ number of successful students at age 16 or 18. Models (4), (5) and (6) show the result of replicating the reducedform, IV and OLS regressions of Table 3 whereas models (8), (9) and (10) show the result of replicating the regressions of panels A, B and C of Table 2. Standard errors are in parentheses. 
Table 5: Effect of the Reform by School Types.

\begin{tabular}{|c|c|c|c|c|}
\hline \multirow[t]{3}{*}{ Panel $A$} & \multicolumn{4}{|c|}{ Simple Difference } \\
\hline & \multicolumn{2}{|c|}{ Grammar } & \multicolumn{2}{|c|}{ Non-grammar } \\
\hline & $\begin{array}{c}\text { Number } \\
\text { students }\left(S_{i c t}\right)\end{array}$ & $\begin{array}{c}\text { Number } \\
\text { Successful at } \\
\text { age } 16\end{array}$ & $\begin{array}{c}\text { Number } \\
\text { students }\left(S_{i c t}\right)\end{array}$ & $\begin{array}{c}\text { Number } \\
\text { Successful at } \\
\text { age } 16\end{array}$ \\
\hline Reform on & 124 & 135 & -044 & $\begin{array}{c}-113 \\
-17\end{array}$ \\
\hline$(c>1978)$ & (.019) & $(.031)$ & $(.020)$ & $(.043)$ \\
\hline Year of Birth $(c)$ & $\begin{array}{l}.011 \\
(.003)\end{array}$ & $\begin{array}{l}.020 \\
(.006)\end{array}$ & $\begin{array}{l}-.008 \\
(.003)\end{array}$ & $\begin{array}{l}.141 \\
(.014)\end{array}$ \\
\hline$(c-1978) \times(c>1978)$ & $\begin{array}{l}-.014 \\
(.004)\end{array}$ & $\begin{array}{l}-.031 \\
(.006)\end{array}$ & $\begin{array}{l}.002 \\
(.005)\end{array}$ & $\begin{array}{l}-.078 \\
(.013)\end{array}$ \\
\hline $\begin{array}{l}\text { Total number } \\
\text { students }\left(S_{i c}\right)\end{array}$ & $\begin{array}{l}.461 \\
(.196)\end{array}$ & $\begin{array}{l}.657 \\
(.298)\end{array}$ & $\begin{array}{l}1.178 \\
(.212)\end{array}$ & $\begin{array}{l}.766 \\
(.339)\end{array}$ \\
\hline$N$ & 207 & 207 & 207 & 207 \\
\hline \multirow[t]{3}{*}{ Panel B } & \multicolumn{4}{|c|}{ Difference in differences } \\
\hline & \multicolumn{2}{|c|}{ Grammar } & \multicolumn{2}{|c|}{ Non-grammar } \\
\hline & $\begin{array}{c}\text { Number } \\
\text { students }\left(S_{\text {ict }}\right) \\
(1)\end{array}$ & $\begin{array}{c}\text { Number } \\
\text { Successful at } \\
\text { age } 16 \\
\text { (2) }\end{array}$ & $\begin{array}{c}\text { Number } \\
\text { students }\left(S_{i c t}\right) \\
\text { (3) }\end{array}$ & $\begin{array}{c}\text { Number } \\
\text { Successful at } \\
\text { age } 16 \\
\text { (4) }\end{array}$ \\
\hline Reform on & 1.423 & 1.391 & -.455 & -1.632 \\
\hline$(c>1978) \times T_{i}$ & $(.686)$ & $(.691)$ & $(.342)$ & $(.810)$ \\
\hline Total number & .509 & .654 & 1.120 & 1.012 \\
\hline students $\left(S_{i c}\right)$ & $(.127)$ & $(.132)$ & $(.109)$ & $(.354)$ \\
\hline$N$ & 207 & 207 & 207 & 207 \\
\hline
\end{tabular}

Note: Panel A replicates the reduced-form analysis of Table 1 using the (log) number of students in grammar schools (column 1), the (log) number of grammar schools' students successful at age 16 (column 2), the (log) number of students in non-grammar schools (column 3) and the (log) number of non-grammar schools' students successful at age 16 (column 4) as dependent variables. Panel B replicates the reduced-form analysis of Table 3 using the same dependent variables. Standard errors are in parentheses. 


\section{Appendix A}

Table A1: Descriptive statistics on the 23 local areas.

\begin{tabular}{|c|c|c|c|c|c|c|c|}
\hline \multirow[b]{2}{*}{ Local Administrative Districts } & \multicolumn{2}{|c|}{ Number of } & $\begin{array}{r}\text { Pre- } \\
\text { (coho } \\
1\end{array}$ & $\begin{array}{l}\text { eform } \\
\text { s 1974- } \\
78)\end{array}$ & $\begin{array}{r}\text { Post-1 } \\
\text { (cohor } \\
19\end{array}$ & $\begin{array}{l}\text { eform } \\
\text { s 1979- } \\
\text { 82) }\end{array}$ & \multirow{2}{*}{$\begin{array}{l}\text { Coef. } \\
\text { of Var. }\end{array}$} \\
\hline & $\begin{array}{c}\text { Elite } \\
\text { Schools }\end{array}$ & $\begin{array}{c}\text { Non } \\
\text { Elite } \\
\text { Schools }\end{array}$ & $\begin{array}{l}\text { Prop. } \\
\text { Elite }\end{array}$ & Weight & $\begin{array}{c}\text { Prop. } \\
\text { Elite }\end{array}$ & Weight & \\
\hline
\end{tabular}

Antrim, Belfast, Carrickfergus, Castelreagh,

Lisburn, Newtonabbey, North Down

Ards, Down

$\begin{array}{ccccccc}7 & 21 & 29.2 & 11.9 & 33.0 & 12.4 & .059 \\ 2 & 6 & 25.0 & 3.3 & 27.9 & 3.4 & .059 \\ 5 & 14 & 28.0 & 7.2 & 28.5 & 7.8 & .038 \\ 3 & 6 & 34.8 & 4.3 & 36.2 & 4.3 & .039 \\ 5 & 8 & 33.5 & 6.1 & 38.4 & 5.8 & .029 \\ 2 & 5 & 33.7 & 2.1 & 35.6 & 1.9 & .108 \\ 2 & 10 & 24.9 & 7.0 & 27.5 & 6.9 & .029 \\ 2 & 7 & 32.2 & 2.5 & 32.6 & 2.5 & .057 \\ 2 & 4 & 47.9 & 2.0 & 48.3 & 2.1 & .042 \\ 1 & 4 & 15.3 & 1.8 & 16.1 & 1.7 & .070\end{array}$

Armagh, Cookstown, Craigavon, Dungannon

Ballymena, Larne, Magherafelt

Banbridge, Newry \& Mourne

Coleraine

Derry, Limavady

Fermanagh

Omagh

16.1

070

\begin{tabular}{|c|c|c|c|c|c|c|c|}
\hline Antrim & 1 & 6 & 24.0 & 1.6 & 29.5 & 1.5 & .107 \\
\hline Ards, North Down & 4 & 7 & 42.7 & 6.1 & 45.0 & 5.6 & .030 \\
\hline Armagh, Banbridge, Craigavon, Newry\&Mourne & 4 & 13 & 38.3 & 5.5 & 36.1 & 6.4 & .043 \\
\hline Ballymena, Larne & 4 & 4 & 42.1 & 3.9 & 47.6 & 3.8 & .073 \\
\hline Belfast, Castelreagh & 10 & 24 & 41.7 & 12.4 & 46.5 & 12.4 & .027 \\
\hline Carrickfergus, Newtonabbey & 3 & 9 & 27.1 & 5.7 & 31.8 & 5.3 & .046 \\
\hline Coleraine & 3 & 6 & 38.3 & 3.7 & 42.4 & 3.5 & .059 \\
\hline Cookstown, Dungannon & 1 & 4 & 17.2 & 2.1 & 21.9 & 1.9 & .068 \\
\hline Derry, Limavady, Omagh, Strabane & 4 & 9 & 33.5 & 4.5 & 36.6 & 4.4 & .046 \\
\hline Down & 1 & 7 & 27.8 & 1.1 & 38.0 & 1.1 & .115 \\
\hline Fermanagh & 2 & 4 & 31.8 & 1.4 & 42.8 & 1.3 & .078 \\
\hline Lisburn & 2 & 5 & 37.7 & 3.2 & 38.9 & 3.0 & .041 \\
\hline Magherafelt & 1 & 2 & 40.4 & 0.9 & 44.6 & 0.9 & .120 \\
\hline Mean outside Belfast: & 2.6 & 6.7 & 32.2 & 3.6 & 35.5 & 3.6 & .062 \\
\hline Std outside Belfast: & 1.3 & 3.0 & 8.3 & 2.0 & 8.4 & 2.1 & .029 \\
\hline Mean including Belfast: & 3.1 & 8.0 & 32.5 & 4.3 & 35.9 & 4.3 & .060 \\
\hline Std including Belfast: & 2.2 & 5.4 & 8.2 & 3.1 & 8.3 & 3.2 & .029 \\
\hline
\end{tabular}


Table A2: Educational Outcomes Before and After the Reform: Descriptive statistics

\begin{tabular}{|c|c|c|c|c|c|c|c|c|}
\hline & \multicolumn{4}{|c|}{ In level } & \multicolumn{4}{|c|}{ In $\log$} \\
\hline & \multicolumn{2}{|c|}{$\begin{array}{c}\text { Pre-Reform } \\
\text { (cohorts 1974- } \\
1978 \text { ) } \\
\end{array}$} & \multicolumn{2}{|c|}{$\begin{array}{c}\text { Post-Reform } \\
\text { (cohorts 1979- } \\
1982 \text { ) } \\
\end{array}$} & \multicolumn{2}{|c|}{$\begin{array}{c}\text { Pre-Reform } \\
\text { (cohorts 1974- } \\
1978) \\
\end{array}$} & \multicolumn{2}{|c|}{$\begin{array}{c}\text { Post-Reform } \\
\text { (cohorts 1979- } \\
1982 \text { ) } \\
\end{array}$} \\
\hline & Mean & Std dev. & Mean & Std dev. & Mean & Std dev. & Mean & Std dev. \\
\hline $\begin{array}{l}\text { Prop. Elite } \\
\left(G_{i c}\right)\end{array}$ & .32 & .08 & .36 & .08 & -1.16 & .28 & -1.06 & .26 \\
\hline $\begin{array}{l}\text { Nb Success. Age } \\
16\end{array}$ & 488 & 360 & 620 & 453 & 5.93 & .74 & 6.17 & .74 \\
\hline $\begin{array}{l}\text { Nb Success. Age } \\
18\end{array}$ & 245 & 200 & 303 & 235 & 5.21 & .79 & 5.44 & .76 \\
\hline $\begin{array}{l}\mathrm{Nb} \text { ent. Higher } \\
\text { Education }\end{array}$ & 265 & 204 & 324 & 247 & 5.30 & .77 & 5.51 & .76 \\
\hline $\begin{array}{l}\mathrm{Nb} \text { benef. from } \\
\text { FSM }\end{array}$ & 347 & 291 & 390 & 326 & 5.49 & .90 & 5.62 & .87 \\
\hline $\begin{array}{l}\text { Total Nb } \\
\text { students }\left(S_{i c}\right)\end{array}$ & 1049 & 743 & 1130 & 822 & 6.71 & .71 & 6.78 & .72 \\
\hline
\end{tabular}




\section{Appendix B}

Table B1: Re-estimation of Equations (1) and (4): a comparison of different specifications.

\begin{tabular}{|c|c|c|c|c|c|}
\hline & \multirow{2}{*}{$\begin{array}{l}\text { First-stage } \\
\text { Prop. Elite } \\
\quad\left(G_{i c}\right)\end{array}$} & \multicolumn{2}{|c|}{ Reduced-form } & \multicolumn{2}{|c|}{ IV } \\
\hline & & $\begin{array}{c}\mathrm{Nb} \\
\text { Success. } \\
\text { Age } 16\end{array}$ & $\begin{array}{c}\mathrm{Nb} \\
\text { Success. } \\
\text { Age } 18\end{array}$ & $\begin{array}{c}\mathrm{Nb} \\
\text { Success. } \\
\text { Age } 16\end{array}$ & $\begin{array}{c}\mathrm{Nb} \\
\text { Success. } \\
\text { Age } 18\end{array}$ \\
\hline & \multicolumn{5}{|c|}{ Equation (1) } \\
\hline Specif. 1 & & & & & \\
\hline $\begin{array}{l}\text { Prop. Elite } \\
\left(G_{i c}\right)\end{array}$ & - & - & - & $\begin{array}{c}.405 \\
(.137)\end{array}$ & $\begin{array}{c}.752 \\
(.100)\end{array}$ \\
\hline $\begin{array}{l}\text { Reform on } \\
(c>1978)\end{array}$ & $\begin{array}{l}.124 \\
(.010)\end{array}$ & $\begin{array}{l}.050 \\
(.018)\end{array}$ & $\begin{array}{l}.093 \\
(.012)\end{array}$ & - & - \\
\hline \multicolumn{6}{|l|}{ Specif. 2} \\
\hline $\begin{array}{l}\text { Prop. Elite } \\
\left(G_{i c}\right)\end{array}$ & - & - & - & $\begin{array}{l}.326 \\
(.226)\end{array}$ & $\begin{array}{l}.830 \\
(.125)\end{array}$ \\
\hline $\begin{array}{l}\text { Reform on } \\
(c>1978)\end{array}$ & $\begin{array}{l}.077 \\
(.019)\end{array}$ & $\begin{array}{l}.025 \\
(.022)\end{array}$ & $\begin{array}{l}.064 \\
(.014)\end{array}$ & - & - \\
\hline \multicolumn{6}{|l|}{ Specif. 3} \\
\hline $\begin{array}{l}\text { Prop. Elite } \\
\left(G_{i c}\right)\end{array}$ & - & - & - & $\begin{array}{l}.678 \\
(.185)\end{array}$ & $\begin{array}{l}.547 \\
(.082)\end{array}$ \\
\hline $\begin{array}{l}\text { Reform on } \\
(c>1978)\end{array}$ & $\begin{array}{l}.039 \\
(.003)\end{array}$ & $\begin{array}{l}.026 \\
(.008)\end{array}$ & $\begin{array}{l}.021 \\
(.007)\end{array}$ & - & - \\
\hline \multicolumn{6}{|l|}{ Specif. 4} \\
\hline $\begin{array}{l}\text { Prop. Elite } \\
\left(G_{i c}\right)\end{array}$ & - & - & - & $\begin{array}{c}.708 \\
(.273)\end{array}$ & $\begin{array}{l}.691 \\
(.140)\end{array}$ \\
\hline $\begin{array}{l}\text { Reform on } \\
(c>1978)\end{array}$ & $\begin{array}{c}.023 \\
(.007)\end{array}$ & $\begin{array}{l}.016 \\
(.010)\end{array}$ & $\begin{array}{c}.016 \\
(.003)\end{array}$ & - & - \\
\hline & \multicolumn{5}{|c|}{ Equation (4) } \\
\hline \multicolumn{6}{|l|}{ Specif. 1} \\
\hline $\begin{array}{l}\text { Prop. Elite } \\
\left(G_{i c}\right)\end{array}$ & - & - & - & $\begin{array}{c}.505 \\
(.262)\end{array}$ & $\begin{array}{c}.854 \\
(.371)\end{array}$ \\
\hline $\begin{array}{l}\text { Reform-on x } \\
T_{i}\end{array}$ & $\begin{array}{l}1.423 \\
(.686)\end{array}$ & $\begin{array}{l}.718 \\
(.521)\end{array}$ & $\begin{array}{l}1.215 \\
(.833)\end{array}$ & - & - \\
\hline \multicolumn{6}{|l|}{ Specif. 2} \\
\hline $\begin{array}{l}\text { Prop. Elite } \\
\left(G_{i c}\right)\end{array}$ & - & - & - & $\begin{array}{l}.500 \\
(.241)\end{array}$ & $\begin{array}{l}.839 \\
(.355)\end{array}$ \\
\hline $\begin{array}{l}\text { Reform-on x } \\
T_{i}\end{array}$ & $\begin{array}{l}1.535 \\
(.702)\end{array}$ & $\begin{array}{l}.768 \\
(.513)\end{array}$ & $\begin{array}{l}1.288 \\
(.804)\end{array}$ & - & - \\
\hline \multicolumn{6}{|l|}{ Specif. 3} \\
\hline $\begin{array}{l}\text { Prop. Elite } \\
\left(G_{i c}\right)\end{array}$ & - & - & - & $\begin{array}{c}.643 \\
(.363)\end{array}$ & $\begin{array}{l}.533 \\
(.286)\end{array}$ \\
\hline $\begin{array}{l}\text { Reform-on x } \\
T_{i}\end{array}$ & $\begin{array}{c}.436 \\
(.222)\end{array}$ & $\begin{array}{l}.280 \\
(.218)\end{array}$ & $\begin{array}{l}.232 \\
(.180)\end{array}$ & - & - \\
\hline \multicolumn{6}{|l|}{ Specif. 4} \\
\hline $\begin{array}{l}\text { Prop. Elite } \\
\left(G_{i c}\right)\end{array}$ & - & - & - & $\begin{array}{c}.631 \\
(.336)\end{array}$ & $\begin{array}{l}.516 \\
(.280)\end{array}$ \\
\hline $\begin{array}{l}\text { Reform-on x } \\
T_{i}\end{array}$ & $\begin{array}{c}.472 \\
(.221)\end{array}$ & $\begin{array}{l}.298 \\
(.211)\end{array}$ & $\begin{array}{l}.244 \\
(.174)\end{array}$ & - & - \\
\hline
\end{tabular}

Note: Specification 1: $\log \left(Y_{i c}\right)$ regressed on $\log \left(G_{i c}\right)$ and $\log \left(S_{i c}\right)$. Specification 2: $\log \left(Y_{i c} / S_{i c}\right)$ regressed on $\log \left(G_{i c}\right)$. Specification 3: $Y_{i c} / S_{i c}$ regressed on $G_{i c}$ and $\log \left(S_{i c}\right)$. Specification 4: $Y_{i c} / S_{i c}$ regressed on $G_{i c}$. Standard errors are in parentheses. 
Table B2: Effect of the Proportion Attending Elite School at Age 11 on Educational Outcomes at Age 16 and 18: A Re-Evaluation Using England as Control Group.

\begin{tabular}{|c|c|c|c|c|c|}
\hline & \multirow[b]{2}{*}{$\begin{array}{l}\text { First-stage } \\
\text { Prop.Elite } \\
\qquad\left(G_{i c}\right) \\
(1)\end{array}$} & \multicolumn{2}{|c|}{ Reduced form } & \multicolumn{2}{|c|}{ IV } \\
\hline & & $\begin{array}{c}\text { Number } \\
\text { Success. } \\
\text { Age } 16 \\
\text { (2) }\end{array}$ & $\begin{array}{c}\text { Number } \\
\text { Success. } \\
\text { Age } 18 \\
\text { (3) }\end{array}$ & $\begin{array}{c}\text { Number } \\
\text { Success. } \\
\text { Age } 16 \\
\text { (4) }\end{array}$ & $\begin{array}{c}\text { Number } \\
\text { Success. } \\
\text { Age } 18 \\
(5)\end{array}$ \\
\hline $\begin{array}{l}\text { Prop. Elite } \\
\left(G_{i c}\right)\end{array}$ & - & - & - & $\begin{array}{l}.861 \\
(.190)\end{array}$ & $\begin{array}{l}.678 \\
(.193)\end{array}$ \\
\hline $\begin{array}{l}\text { Reform on } \\
(c>1978) * N I\end{array}$ & $\begin{array}{l}.165 \\
(.024)\end{array}$ & $\begin{array}{l}.164 \\
(.034)\end{array}$ & $\begin{array}{l}.112 \\
(.039)\end{array}$ & - & - \\
\hline$N$ & 192 & 168 & 192 & 168 & 192 \\
\hline \multicolumn{6}{|c|}{$\begin{array}{l}\text { Note: Model (1) shows the result of regressing the (log) proportion of students attending grammar schools on a } \\
\text { variable interacting a "Northern Ireland" dummy and a "Reform on" dummy, using } 24 \text { area fixed effects ( } 23 \\
\text { Northern Ireland areas + England), } 9 \text { cohort fixed effects, (log) cohort size and (log) cohort size interacted with } \\
\text { the "Northern Ireland" dummy as control variables. Model (3) and (4) shows the results of regressing the (log) } \\
\text { number of students successful at age } 16 \text { and } 18 \text { on the same independent variables. Models (4) and (5) show the } \\
\text { corresponding IV regressions. Standard errors are in parentheses. English data on educational outcomes are } \\
\text { available from cohort } 1975 \text { onward for age } 18 \text { outcomes and from cohort } 1976 \text { onward for age } 16 \text { outcomes, } \\
\text { which explains the smaller sample size for the analysis of age } 16 \text { outcome. }\end{array}$} \\
\hline
\end{tabular}

Table B3: Effect of the Reform on the Number of Students Benefiting from Free School Meals.

Dependant var. : (log) proportion students eligible free school meals

\begin{tabular}{ccc} 
Simple Diff. & Long Diff. & Diff-in-Diff. \\
(Eq. (2)) & (Eq. (3)) & (Eq. (5)) \\
\hline
\end{tabular}

$\begin{array}{lccc}\text { Reform on } & .015 & - & - \\ \left(\mathrm{G}_{i, a f t e r}-\mathrm{G}_{i, \text { before }}\right) & (.058) & -.043 & - \\ \text { Reform on x } T_{i} & - & (.452) & -1.426 \\ N & - & - & (.876) \\ N & 161 & 23 & 161\end{array}$

Note: column 1 provides the effect of the reform on the proportion of pupils eligible to free school meals in an area using the same reduced-form specification as in table 1, whereas column 2 uses the same specification as panel A of Table 2 and column 3 the same reduced-form specification as in table 3. The size of the sample used for replicating simple-difference and difference-in-differences is $\mathrm{N}=161$ only, because data on free school meals are not available for cohorts 1974 and 1975. Standard errors are in parentheses. 
Table B4: Regressions Using Cluster Aggregated Outcomes.

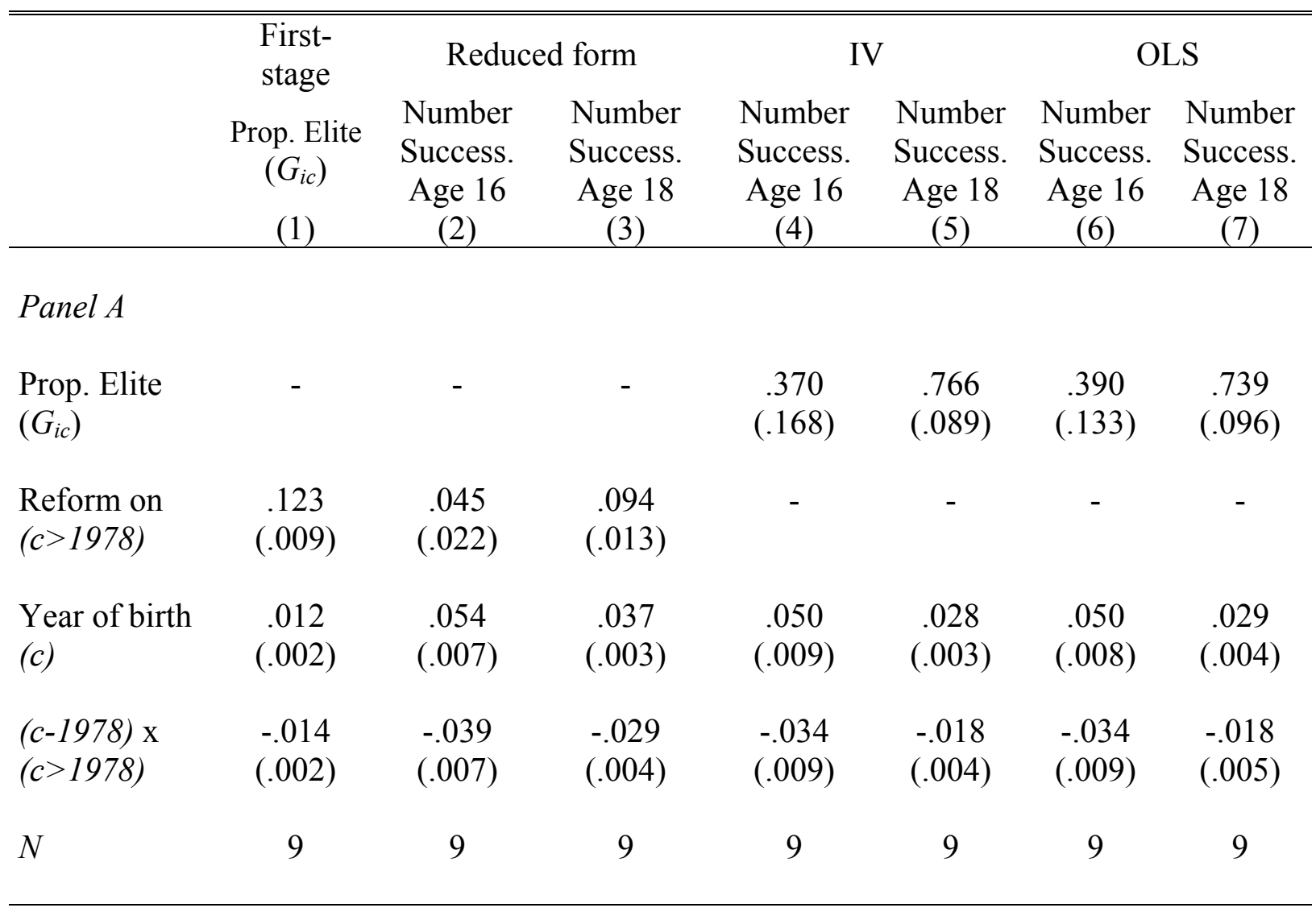

Panel B

\begin{tabular}{|c|c|c|c|c|c|c|c|}
\hline $\begin{array}{l}\text { Prop. Elite } \\
\left(G_{i, c}\right)\end{array}$ & - & - & - & $\begin{array}{l}.505 \\
(.257)\end{array}$ & $\begin{array}{c}.860 \\
(.359)\end{array}$ & $\begin{array}{c}.463 \\
(.148)\end{array}$ & $\begin{array}{c}.770 \\
(.196)\end{array}$ \\
\hline $\begin{array}{l}\text { Reform on } \mathrm{x} \\
T_{i}\end{array}$ & $\begin{array}{l}1.439 \\
(.690)\end{array}$ & $\begin{array}{l}.726 \\
(.514)\end{array}$ & $\begin{array}{l}1.237 \\
(.830)\end{array}$ & - & - & - & - \\
\hline$N$ & 46 & 46 & 46 & 46 & 46 & 46 & 46 \\
\hline
\end{tabular}

Note: Panel A replicates Table 1 after aggregating outcomes at the cohort level (9 clusters) and purging the effect of regressors varying within cohort using the results of a first-step cohort fixed effect model. Panel B replicates Table 3 after aggregating outcomes at the area*reform-on level (46 clusters) and purging the effect of regressors varying within clusters using the results of a first-step cluster fixed effect model. The regressions in panel B include a set of 23 area dummies and 1 "reform on" dummy as additional control variables. In panel A the number of degrees of freedom is $5=9-4$ and the rejection point at the $5 \%$ level (10\%) for the $T$ statistics is 2.57 (2.02). In panel $\mathrm{B}$, the number of degree of freedoms is $21=46-25$ and the rejection point at the $5 \%(10 \%)$ level for the $T$ statistics is 2.08 (1.72). Standard errors are in parentheses. 


\section{Appendix C}

The combination and re-combination of the three ability groups $A, B$ and $C$ define two school contexts before the reform ( $s=A$ for grammar schools and $s=B+C$ for non grammar) and two new school contexts after the reform ( $s=A+B$ for grammar, $s=C$ for non grammar). If we denote $y_{\mathrm{s}}(\mathrm{g})$ the average outcome of ability group $g$ in school context $s$, the average outcome in grammar school is $y_{\mathrm{A}}(\mathrm{A})$ before the reform and $q_{\mathrm{A}} y_{\mathrm{A}+\mathrm{B}}(\mathrm{A})+q_{\mathrm{B}} y_{\mathrm{A}+\mathrm{B}}(\mathrm{B})$ after the reform, where $q_{\mathrm{A}}$ represents the weight of group $\mathrm{A}$ in grammar school after the reform (and $q_{\mathrm{B}}=1-q_{\mathrm{A}}$ ). Using this notation, the effect of the reform on the average outcomes of grammar schools is,

$$
\Delta(\mathrm{G}) \equiv\left(q_{\mathrm{A}} y_{\mathrm{A}+\mathrm{B}}(\mathrm{A})+q_{\mathrm{B}} y_{\mathrm{A}+\mathrm{B}}(\mathrm{B})\right)-y_{\mathrm{A}}(\mathrm{A}),
$$

which can be rewritten,

$$
\Delta(\mathrm{G})=q_{\mathrm{A}}\left[y_{\mathrm{A}+\mathrm{B}}(\mathrm{A})-y_{\mathrm{A}}(\mathrm{A})\right]+q_{\mathrm{B}}\left[y_{\mathrm{A}+\mathrm{B}}(\mathrm{B})-y_{\mathrm{A}}(\mathrm{A})\right] .
$$

This expression shows that the effect of the reform on average outcomes in grammar schools is a weighted average of an ability effect (i.e., $\left.y_{\mathrm{A}+\mathrm{B}}(\mathrm{B})-y_{\mathrm{A}}(\mathrm{A})\right)$ and a contextual effect (i.e., $\left(y_{\mathrm{A}+\mathrm{B}}(\mathrm{A})-y_{\mathrm{A}}(\mathrm{A})\right)$. This contextual effect is precisely the effect on top ability pupils ( $A$ pupils) of having new peers, with relatively lower ability (B pupils).

Given this fact, it is clear that $\Delta(\mathrm{G})$ does not point identify the contextual effect of the reform on top ability students. However, under the assumption that pupils who are top ability at age 11 perform better at age 16 or 18 than pupils who are only mid-ability (i.e., $y_{\mathrm{A}+\mathrm{B}}(\mathrm{B})<$ $\left.y_{\mathrm{A}+\mathrm{B}}(\mathrm{A})\right)$, it is easy to check that it provides a lower bound for this specific contextual effect. Specifically, under the simple assumption that $y_{\mathrm{A}+\mathrm{B}}(\mathrm{B})<y_{\mathrm{A}+\mathrm{B}}(\mathrm{A})$, we have,

$$
\Delta(\mathrm{G})<y_{\mathrm{A}+\mathrm{B}}(\mathrm{A})-y_{\mathrm{A}}(\mathrm{A}) .
$$

Hence, $\Delta(\mathrm{G})$ provides us with a plausible lower bound for the potentially depressing contextual effect of the reform on top ability pupils. With respect to the effect of the reform on non-grammar schools, we have,

$$
\Delta(\mathrm{NG})=y_{\mathrm{C}}(\mathrm{C})-\left(p_{\mathrm{B}} y_{\mathrm{B}+\mathrm{C}}(\mathrm{B})+p_{\mathrm{C}} y_{\mathrm{B}+\mathrm{C}}(\mathrm{C})\right),
$$

where $p_{\mathrm{B}}$ represents the weight of group $\mathrm{B}$ in non-grammar school before the reform (and $p_{\mathrm{C}}$ $\left.=1-p_{\mathrm{B}}\right)$. Under the simple assumption that pupils who are mid-ability at age 11 perform better at age 16 or 18 than low ability pupils (i.e., $y_{\mathrm{B}+\mathrm{C}}(\mathrm{C})<y_{\mathrm{B}+\mathrm{C}}(\mathrm{B})$ ), it is again not very difficult to show that $\Delta(\mathrm{NG})$ provides an interesting lower bound for the contextual effect of the reform on low ability pupils, i.e. a lower bound for $\left(y_{C}(C)-y_{B+C}(C)\right.$. Specifically, under the sole assumption that $y_{\mathrm{B}+\mathrm{C}}(\mathrm{C})<y_{\mathrm{B}+\mathrm{C}}(\mathrm{B})$ we have,

$$
\Delta(\mathrm{NG})<y_{\mathrm{C}}(\mathrm{C})-y_{\mathrm{B}+\mathrm{C}}(\mathrm{C}) .
$$

Assuming that there is no negative externality on group A (i.e., $\left(y_{\mathrm{A}+\mathrm{B}}(\mathrm{A})=y_{\mathrm{A}}(\mathrm{A})\right)$, and using $\Delta(\mathrm{G})=\left(\mathrm{q}_{\mathrm{A}} y_{\mathrm{A}+\mathrm{B}}(\mathrm{A})+\mathrm{q}_{\mathrm{B}} y_{\mathrm{A}+\mathrm{B}}(\mathrm{B})\right)-y_{\mathrm{A}}(\mathrm{A})$, our results that $\Delta($ Grammar $)=0$ implies that $y_{\mathrm{A}+\mathrm{B}}(\mathrm{B})=y_{\mathrm{A}}(\mathrm{A})$ i.e., group $\mathrm{B}$ post-reform does as well as group A pre-reform. 